\title{
A Method for Assessing Regional Bioenergy Potentials Based on GIS Data and a Dynamic Yield Simulation Model
}

\author{
Keyu Bao ${ }^{1, *}$, Rushikesh Padsala ${ }^{2} \mathbb{D}$, Volker Coors ${ }^{2}$, Daniela Thrän ${ }^{3,4,5}$ and Bastian Schröter ${ }^{1} \mathbb{D}$ \\ 1 Center for Sustainable Energy Technology, Hochschule für Technik Stuttgart, Schellingstraße 24, \\ D-70174 Stuttgart, Germany; bastian.schroeter@hft-stuttgart.de \\ 2 Center for Geodesy and Geoinformatics, Hochschule für Technik Stuttgart, Schellingstraße 24, \\ D-70174 Stuttgart, Germany; rushikesh.padsala@hft-stuttgart.de (R.P.); volker.coors@hft-stuttgart.de (V.C.) \\ 3 Department of Bioenergy, Helmholz Center for Environmental Research, Torgauer Strasse 116, \\ D-04247 Leipzig, Germany; daniela.thraen@ufz.de or thraen@wifa.uni-leipzig.de or daniela.thraen@dbfz.de \\ 4 Chair of Bioenergy System, Faculty of Economic Sciences, University of Leipzig, Grimmaische Straße 12, \\ D-04109 Leipzig, Germany \\ 5 Unit Bioenergy System, Deutsches Biomasseforschungszentrum GmbH, Torgauer Strasse 116, \\ D-04347 Leipzig, Germany \\ * Correspondence: keyu.bao@hft-stuttgart.de
}

Received: 16 November 2020; Accepted: 2 December 2020; Published: 8 December 2020

\begin{abstract}
The assessment of regional bioenergy potentials from different types of natural land cover is an integral part of simulation tools that aim to assess local renewable energy systems. This work introduces a new workflow, which evaluates regional bioenergy potentials and its impact on water demand based on geographical information system (GIS)-based land use data, satellite maps on local crop types and soil types, and conversion factors from biomass to bioenergy. The actual annual biomass yield of crops is assessed through an automated process considering the factors of local climate, crop type, soil, and irrigation. The crop biomass yields are validated with historic statistical data, with deviation less than $7 \%$ in most cases. Additionally, the resulting bioenergy potentials yield between 10.7 and $12.0 \mathrm{GWh} / \mathrm{ha}$ compared with $13.3 \mathrm{GWh} / \mathrm{ha}$ from other studies. The potential contribution from bioenergy on the energy demand were investigated in the two case studies, representing the agricultural-dominant rural area in North Germany and suburban region in South Germany: Simulation of the future bioenergy potential for 2050 shows only smaller effects from climate change (less than $4 \%$ ) and irrigation (below 3\%), but the potential to cover up to $21 \%$ of the transport fuels demand in scenario supporting biodiesel and bioethanol for transportation.
\end{abstract}

Keywords: potential analysis; geographical information system (GIS); bioenergy; AquaCrop

\section{Introduction}

Although the metabolism of industrial societies strongly relies on minerals and fossilized biomass, annually harvested biomass from vegetation contributes about $10 \%$ to primary energy use in the European Union [1]. Biomass can be derived from different resources, e.g., agricultural land or forest, and transferred into different forms of bioenergy, e.g., biogas, liquid, and solid fuel. In decentralized and renewable energy systems, bioenergy can play important roles in fueling the parts of the transport sector that cannot be easily electrified, or in securing controllable electricity supply that can counteract fluctuations of intermittent wind and photovoltaic power sources [2]. It is therefore important to assess regional biomass potentials and to understand the possible variables that might influence the potential in order to help local governments and planning authorities to make informed choices regarding 
the potentials and trade-offs between different renewable energy sources (RESs) on a strategic level, especially improve understanding of future energy supply systems with high shares of renewables. The resource focused assessment is adapted in this paper, which takes the form of inventories of potential bioenergy sources, with an evaluation of possibilities to utilize the sources for energy purpose [3]. The method thus needs to be reasonably accurate in the context of local energy systems and build upon a similar data structure as the methods already implemented, such as assessments of rooftop photovoltaic (PV) potentials [4] or the energy demand for heating on the city quarter level [5], but it does not need to be able to compete with specialized tools that focus for example solely on assessing local potentials of one RES.

Biomass potential assessments so far are widely used for either specific types of land use and biomass, e.g., forests [6], or highly aggregated scenarios, since their focus lies on providing data on a national or supranational level [7]. For the first, e.g., D. Lauka et al. introduced a model that is able to assess low-quality biomass resources, e.g., solid fuel directly for burning, and potential, but without taking biogas or bioethanol potentials into account [8], while the technical potential for power production from forest biomass was assessed in [6]. For the second, biomass potentials in various scenarios on a national level are evaluated for example in [7].

Moreover, methods based on GIS are widely applied to assess biomass potentials [9-12]. Ref. [9,10] both focus on residue potential; [11] analyzed forest biomass potential; and [12] assesses the suitable power plant location based on biomass potential. They typically overlay various layers of data (such as forest, agriculture, urban, slope, and road) in order to define suitable areas with biomass potentials. However, typically only a statistical crop distribution is applied to aggregated feasible lands because of a lack of crop distribution maps. Those methods are thus limited in their degree of accuracy and simplicity.

To the authors' knowledge, there are a lack of models that combine biomass potential assessments with other RES sources, most importantly solar photovoltaics and wind, on the regional level in one aggregated modeling and simulation environment. Such an approach is of great benefit if the goal is to assess local synergies, potential conflicts, economic merit orders, or summed potentials of RES sources and contrast these with local demands.

This paper introduces a newly established bioenergy assessment method that fills this gap. The accuracy of the method is brought by applying (i) high-resolution soil and crop distribution GIS maps. (Section 2.1) (ii) Dynamic yield simulation model that takes environmental factors, crop species, and soil texture into consideration (Sections 2.2 and 2.3). This workflow adapts the resource-focused assessments (Section 2.4), which take the form of inventories of potential bioenergy sources, with an evaluation of possibilities to utilize the sources for energy purposes. The versatility of this method is brought by extending an existing local energy system simulation platform that can assess heat and power demands in residential areas [13] and rooftop photovoltaic potentials [14] on a single-building level (Section 2.5). The method is validated through the examples of three counties with different land cover characteristics in Germany (Section 2.6). Scenarios concerning climate change, transportation fuel, and irrigation are illustrated demonstrating the possible applications of the method (Sections 2.7 and 2.8). As followed, the results of scenarios analysis are summarized in Section 3. Section 4 discusses the result and the advantage and limitation of the method. In the end Section 5 conclude the novelty of the method as a feasible tool for regional bioenergy analysis under the framework of Food-Water-Energy (FWE) nexus.

\section{Materials and Methods}

\subsection{Input Data}

The primary input data for the newly established workflow consists of the digital landscape model (DLM) data in the shapefile data format provided by Germany's Official Real Property Cadastre Information System (ALKIS) [15]. ALKIS was developed by the Working Group of the Surveying 
Authorities of the sixteen states of Germany (AdV). The DLM map consists of several object layers, including buildings, water bodies, vegetation, transportation, etc. Since the land area dedicated to transportation is stored as line geometry, a buffer with road width is created in the transportation layer and overlapped with the vegetation layer. The intersected part of the vegetation layer is cropped out to avoid its inflation. For each polygon in the vegetation layer of the DLM map information on vegetation land use type, land area in meter and polygon boundary coordinates were included. DLM data is derived from the topographic map with a resolution of 1:10,000/1:25,000 and for linear features resolution of $\pm 3 \mathrm{~m}$.

DLM data accurately indicate the boundary and land use of each polygon. However, the specific crop type for agricultural polygons is missing. To fill this gap, the DLM data was combined with satellite data on crop types from [16]. There, Griffiths et al. derive a map of crop types and land cover from satellite data, and compare their results to agricultural reference data from three (German) states and to the results of a national agricultural census. The resulting raster map captured the crop type distribution across Germany at $30 \mathrm{~m}$ resolution and achieved $81 \%$ overall accuracy for 12 classes in the three states. For several crops, notably cereals, maize, and rapeseed, mapped acreages compared very well with the official census data, with differences of $11 \%, 2 \%$, and $3 \%$, respectively. Other classes (grapevine and forest classes) performed less well, likely because the available reference data did not fully capture the variability of these classes across Germany. The land use and crop types differentiated in [16] are shown in Table 1.

Table 1. Land use and crop category used in this study. Data adapted from $[15,16]$.

\begin{tabular}{lll}
\hline $\begin{array}{l}\text { Crop Type Only Specified in } \\
\text { Satellite Map }\end{array}$ & $\begin{array}{l}\text { Crop Type Specified in Both } \\
\text { DLM and Satellite Map }\end{array}$ & $\begin{array}{l}\text { Crop Type Only Specified } \\
\text { DLM Map }\end{array}$ \\
\hline Winter cereals & Grassland & Short Rotation Coppice \\
Spring cereals & Grapevine & Fruit orchard \\
Maize & Deciduous mix forest & Fruit orchard in grassland \\
Winter rapeseed & Coniferous forest & Fruit orchard in farming land \\
Sugar beet & Built-up & Grove \\
Potato & Water & \\
\hline
\end{tabular}

Conflicts between maps from different sources are common, since they were derived with different methods and were based on different primary sources. Generally, the DLM data has a high level of accuracy and reliability in terms of overall land use type, e.g., farming land, vineyard, or built-up area, when compared with satellite data, e.g., from Google Maps. Therefore, the polygons from this source serve as the basic unit when merging the two sources [15]. In the case of a conflict regarding overall land use, DLM data is prioritized. Crop information [16] is then attached to each DLM polygon as an additional attribute. In case multiple crop types from [16] exist on the same DLM polygon, which for agricultural land mostly refers to individual fields, the land use type with the largest area share is assigned to this polygon. Generally, only areas classified as agricultural in the DLM map are attached with additional crop type information from [16].

Plant-soil relationships in the surface soil layer affect crop productivity [17]. For example, yields of Miscanthus range from 5 to $13 \mathrm{t} /$ (ha a) on poor soil or marginal land, while from 7 to $44 \mathrm{t} /$ (ha a) on arable land with higher-quality soils [18]. Therefore, local soil types should be considered to achieve a more accurate biomass or bioenergy yield simulation. For this, a map showing the distribution of typical soil types (soil texture) in the top soils of Germany (resolution 1:100,000) from the Federal Institute for Geosciences and Natural Resources [19] was overlaid with the enriched DLM map. Considering the large heterogeneity in the data and the resulting uncertainty in the precision for a given site, the depiction of the obtained soil texture is presented at the level of the soil types group, according to the German soil classification system (KA5) [19] and as shown in Appendix A.

Figure 1 shows the original DLM, crop data, soil data, and the superimposed data at the example of the city of Marbach, Ludwigsburg county, in the south-western state of Baden-Württemberg. It is 
transformed into the open CityGML data format [20], in order to use the combined map data within the structure of our existing modeling environment [21].

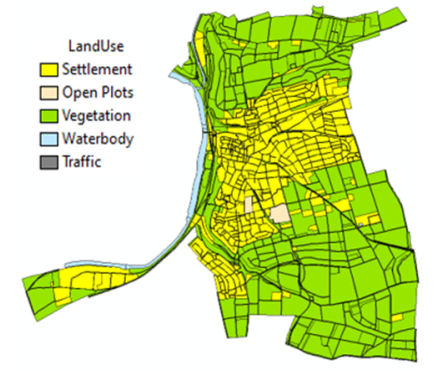

(a) DML

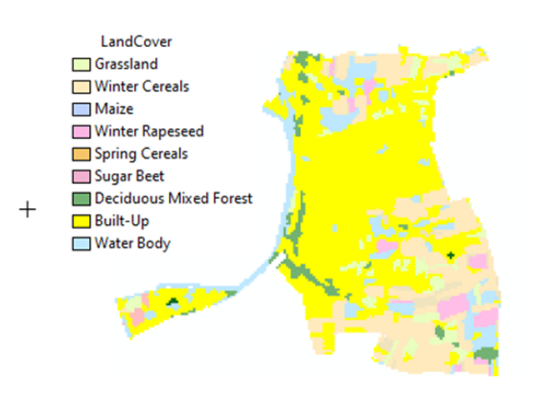

(b) Crop distribution

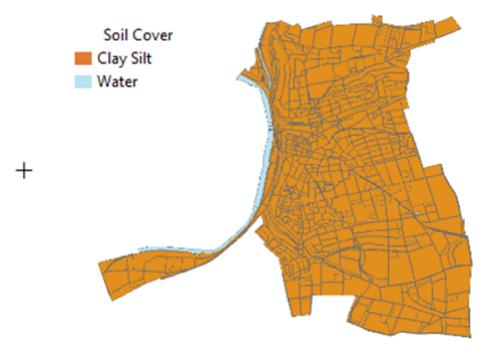

(c) Soil distribution

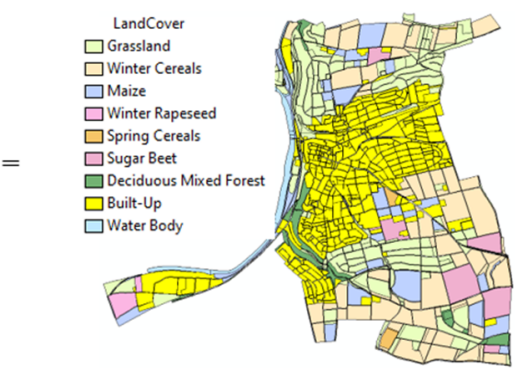

(d) Overlay

Figure 1. Set of input and resulting maps for Marbach, Ludwigsburg county, Baden-Württemberg. (a) Digital landscape model (DLM) map in polygons with land use; (b) satellite map in raster with crop type; (c) soil map; and (d) overlay of (a) and (b).

The accuracy of the thus created CityGML data set was validated by comparing it to statistical data for Ludwigsburg county. The county's total land area, classified into the main forms of land use, was compared with the total land area from the state's 2018 land use report [22]. As Table 2 shows, the total area dedicated to agriculture and forest differed by only 3.2\%, and the farming area by less than $7 \%$. Grassland and garden areas show larger differences between, with possible reasons being (i) that the DLM dataset only counted polygons with areas of more than one hectare, with smaller fields not included in the dataset in the first place and (ii) that the DLM dataset contained more categories than the state land use report. For instance, orchard meadows, tree nurseries, and fruit plantations are part of the created GML map, but not the land use report. Since orchard meadow could for example be regarded as grassland with fruit trees, combining both categories yield a sum (8210 ha) that is closer to the grass land area from the land use report (7967 ha). Similarly, adding nurseries and fruit plantations to the garden category reduced this initial difference.

\subsection{Assessment Method for Local Biomass Potential}

Biomass potentials can be distinguished between theoretical, technical, economic, exploitable, and sustainable potentials.

The theoretical potential describes the potential that exists in a given region within a certain time period of physically usable energy supply, e.g., the energy stored in the entire plant mass. It is determined by physical limits and marks the upper limit of bioenergy's theoretically realizable contribution to energy supply. Due to insurmountable technical, ecological, economic, and administrative barriers, this potential can generally only be tapped to a limited extent. It therefore has no practical relevance for assessing the actual usability of biomass [23].

The technical potential describes that part of the theoretical potential that can be used after taking into account technical restrictions, e.g., salvage rate, storage losses, and conversion losses. 
In addition, existing structural and ecological restrictions and other legal requirements and possible social restrictions are taken into account, as they represent barriers to the use of bioenergy similar to technically induced restrictions [23]. In the following, the technical bioenergy potential is the potential after processing (e.g., pelletizing, pyrolysis, and methanization) in the form of secondary energy carriers (biomethane, biodiesel, bioethanol, and burning fuel) or primary energy carriers (energy wood and residues) destined for combustion.

Table 2. Ludwigsburg county: comparison of the summed value of land area in the created CityGML file and in the state's 2018 land use report. Statistical land area data is adapted from [22].

\begin{tabular}{llccc}
\hline & & Area, Land Use Report [22] & Area, GML Map & Difference \\
\hline Agriculture & & $\mathbf{( h a )}$ & $\mathbf{( h a )}$ & $\mathbf{( \% )}$ \\
\hline \multirow{6}{*}{ Of which } & 37,704 & 36,493 & 3.2 \\
& Farming & 26,990 & 25,150 & 6.8 \\
& Grass & & & \\
& Orchard meadow & 7967 & 3417 & 57.1 \\
& Sum of grass and orchard meadow & - & 4793 & - \\
& Garden & 7967 & 8210 & 3.1 \\
& Tree nursery & 549 & 234 & 57.4 \\
& Fruit plantation & - & 137 & - \\
& Vineyard & - & 467 & - \\
& Brown land & 2198 & 2292 & 4.3 \\
\hline Forest & & 0 & 0 & 0.0 \\
\hline
\end{tabular}

In order to calculate the biomass yield considering climate, soil situation, land management, and irrigation patterns, an external crop yield and water demand model, AquaCrop, was integrated into our energy simulation environment (see also the next section). The amount of biomass produced over the course of a growing season on a given area is given as one of the outputs of AquaCrop, which can be considered as the yield of the crop and starting point for assessing bioenergy potentials [24]. By applying conversion factors to theoretical and technical energy yields, the energy potential at these two levels can be calculated and given as the output of the energy simulation model.

It has to be noted that the dynamic yield modeling only applies to field crops, grass, and short rotation coppice, while not to forests and fruit plantations, as the AquaCrop's model does not apply to tree-based biomass creation. Moreover, woody biomass as residue is collected only under the situations of the clearing of fields and of irregular intervals, when trees are felled because of excessive age, diseases, and/or storm damage [23]. The woody biomass from these sources is accumulated through several years. In this paper harvesting of energy crops were simulated at the annual base. Therefore, in this simulation the yield of vineyard, bushes, fruit planation, and orchard meadow have the static raw biomass yield from the literature [23]. The potentials calculated in this paper as well as their calculation methods are summarized in Table 3.

\subsection{Dynamic Yield Model}

AquaCrop is a model that describes the interactions between the plant, atmospheric factors, and the soil. From the root zone, the plant extracts water and nutrients. Calculation scheme of AquaCrop is affected by water stress and temperature stress [24]. The accumulation of biomass and transpiration of crop are influenced by crop type, atmospheric temperature, rainfall, irradiation, $\mathrm{CO}_{2}$ concentration, irrigation, ground water level, and fertilization. In this study the ground water level and fertilization are not included in the yield model. With the help of the dynamic yield model a more accurate biomass yield can be retrieved for the further simulation. The local climate, soil texture, or even irrigation can result in very different yield values than the typical statistical values.

The aim of the new bioenergy potential workflow is to extract the amount of above-ground biomass indicated, which is the starting point for further bioenergy conversion processes. The biomass 
produced is proportional to the cumulative amount of crop transpiration $(\Sigma T r)$, with the biomass water productivity (WP) in dry mass as the proportionality factor. Normalization for climatic conditions yields normalized biomass water productivity (WP*), valid for diverse locations, seasons, and $\mathrm{CO}_{2}$ concentrations [24]. Water in the soil that is easily extracted by the plant is called readily available water (RAW). Hereby, water stress is defined as the percentage of RAW in the root zone, with $0 \%$ meaning the soil water is at field capacity, which is ideal for crop growing, and $100 \%$ representing the threshold of stomatal closure.

Table 3. Calculation approach to biomass potentials for different crops and types of biomass.

\begin{tabular}{|c|c|c|c|c|}
\hline \multirow[b]{2}{*}{ Land Cover Type } & \multicolumn{3}{|c|}{ Calculable Potentials } & \multirow{2}{*}{$\begin{array}{l}\text { Method } \\
\text { Used }\end{array}$} \\
\hline & Theoretical & $\begin{array}{c}\text { Technical, Excluding } \\
\text { Residues }\end{array}$ & $\begin{array}{c}\text { Technical Only, } \\
\text { Including Residues }\end{array}$ & \\
\hline Winter cereals & $\mathrm{x}$ & $\mathrm{x}$ & $\mathrm{x}$ & AquaCrop \\
\hline Spring cereals & $\mathrm{x}$ & $\mathrm{x}$ & $\mathrm{x}$ & AquaCrop \\
\hline Maize & $x$ & $x$ & $x$ & AquaCrop \\
\hline Winter rapeseed & $x$ & $x$ & $x$ & AquaCrop \\
\hline Sugar beet & $x$ & $x$ & $x$ & AquaCrop \\
\hline Potato & $x$ & $\mathrm{x}$ & $x$ & AquaCrop \\
\hline Short Rotation Coppice (SRC) & $\mathrm{x}$ & $\mathrm{x}$ & $\mathrm{x}$ & AquaCrop \\
\hline Grassland & $x$ & $x$ & $x$ & AquaCrop \\
\hline Grapevine & & & $x$ & Static \\
\hline Bushes and hedges & & & $x$ & Static \\
\hline Deciduous and mix forest & $x$ & & & Static \\
\hline Coniferous forest & $\mathrm{x}$ & & & Static \\
\hline \multicolumn{5}{|l|}{ Built-up } \\
\hline \multicolumn{5}{|l|}{ Water } \\
\hline Fruit orchard & & & $x$ & Static \\
\hline Fruit orchard in grassland & & & $x$ & Static \\
\hline Fruit orchard in farming land & & & $x$ & Static \\
\hline
\end{tabular}

\subsection{Calculation of Bioenergy Potentials}

The calculation of theoretical potential is required for the calculation of technical potentials in a next step. The theoretical energy potential of a certain form of biomass can be described by its heating value, multiplied with its dry mass production yield and its water content percentage, with production yields calculated by taking environmental factors including temperature, precipitation, irradiation, soil texture, and irrigation into account (as discussed in Section 3.3).

As explained in Section 3.2, the technical potential of crops and grass can be derived from the theoretical potential by applying conversion coefficients including conversion losses, and the percentage that are used for energetic purposes. As a first step, the distribution between energy and food is defined for specific crops. Secondly, for the part that is used energetically, in most cases more than one type of secondary (bio-)energy carrier can be obtained per crop, so the respective shares need to be determined. Thus, multiplying bioenergy conversion coefficients with the amount of available biomass allows one to calculate the technical potential of a certain crop in a certain form of bioenergy. Here, the solid bioenergy potential is set equal to the theoretical potential of any crop type. This process is pursued for each land field, each crop type, and each possible form of bioenergy. It has to be noted that the thus calculated technical potential is the potential of the crop used for energetic purposes only. Regardless of whether the crop is used for food purpose or energy purpose, its byproducts, e.g., grain straw or leaf mass, are always considered to have technical energy potential of residue.

Of the harvested forest wood, around $26 \%$ are utilized for an energetic purpose in Germany [25], making it an important contributor to local bioenergy potentials, especially in rural and mountainous regions. However, given that the growth of forest biomass is also dependent on other factors than soil, climate, and temperature, notably groundwater levels [26], it is much more difficult to model dynamically. Therefore, a static value for the annual technical potential of forest-based bioenergy (in the form of energy wood) is assumed in the following. 
Similar to forest, we used literature values of the biomass yield potential of orchard, vineyard, and bushes/hedges. A limited share of the biomass from annual pruning in landscape conservation areas is used as solid residue, since its collection is often complex and expensive.

Finally, all formulas and related parameters for the calculation of biomass and bioenergy potentials for the most widely spread crops in Germany are given in Appendix B.

\subsection{Simulation Environment and Interface}

As mentioned earlier, the assessment of biomass potentials is to be included in an existing modeling environment in order to compare different RES potentials and contrast these with energetic demands in a given region (Figure 2). The modeling environment SimStadt developed at HFT Stuttgart allows one to assess electricity, cooling and heat demands, and renewable energy potentials (photovoltaic) on a single-building level using 3D city models (in the CityGML format [21]). SimStadt provides a modular workflow management for various, primarily energetic, system analysis purposes. Each workflow serves a specific purpose, e.g., heating demand of buildings or photovoltaic potential, while certain modules are shared between workflows, e.g., importing data or data preprocessing [27].

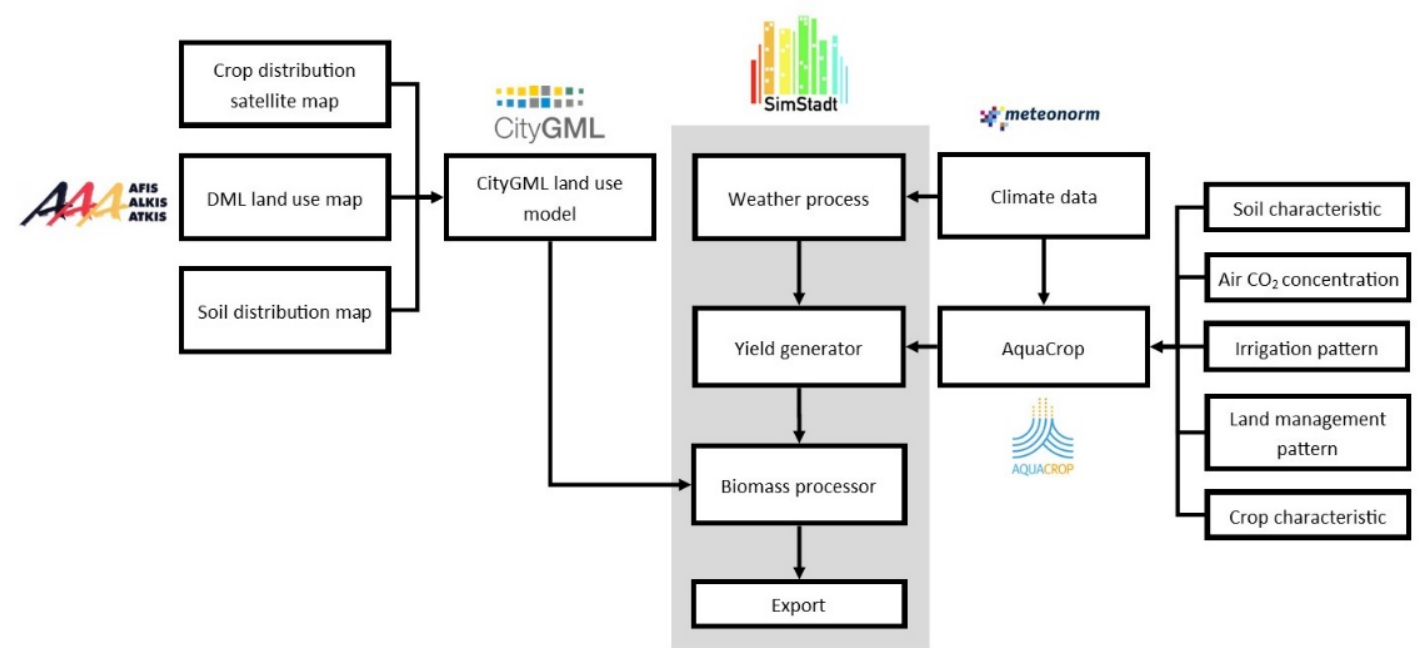

Figure 2. Flow chart of the newly established SimStadt bioenergy workflow.

For the newly established workflow on regional bioenergy potentials, most of the predefined modules are not applicable due to the fact that the input data is land use polygons instead of building geometries, the exception being the import module that can read CityGML files regardless of the type of objects (building or land use polygon) and the weather model that imports the meteorological data in TMY3 format generated by Meteonorm for the specific region in hourly or monthly resolution. The meteorological data are stored in SimStadt and can be called in later steps.

To model bioenergy potentials more accurately than by using static values for all crops, a new module "YieldGenerator" was developed. Firstly, climate data, including daily precipitation and temperature data from the step "WeatherProcessor" is read, converted, and saved in a form that AquaCrop can process. Secondly, the crop reference evapotranspiration (ETo) is determined from meteorological data, including latitude, longitude, altitude, temperature, relative humidity, wind speed, and cloud shading. The FAO Penman-Monteith method [28] was used for the computation of ETo from meteorological data. These meteorological data were called and calculated according to the Penman-Monteith method on a daily basis over a whole year. Thirdly, irrigation patterns are assigned to crops. In this paper we were interested in the net water demand of a crop to determine the amount of potential irrigation required, on top of precipitation, in a given environment. Net irrigation requirement was calculated by adding a certain amount of water to the soil profile each day in case the local soil water content itself was not sufficient for a given crop type. Fourthly, project files for each crop on all 
possible soil types in a given region were generated by the workflow, which serve as the main input to the AquaCrop model; all required crop parameters are listed in Appendix C. To limit the complexity of the model, we assumed the soil profile of each soil type was deep $(>1.5 \mathrm{~m})$ and uniform, regardless of the possibility that soils could have several layers with different characteristics. Fifthly, the AquaCrop Plug-In was called from SimStadt; as output, the annual biomass incremental yield in $t /$ (ha a) and water demand, including potential irrigation demands, in millimeters of all crops on all soil types were stored in an XML configuration file extending other input settings, e.g., the conversion pathways to different bioenergy forms per relevant crop, static default biomass yields, or bioenergy conversion factors from raw biomass.

Another module, "BiomassProcessor" then processes all land use polygons. Users can modify parameters, such as the annual forest wood energetic use rate, the share of energy crops such as corn and rapeseed that are actually used for energetic purposes, or the grass land energy usage rate. The default variables values are shown in Appendix D where data are collected and adapted from $[23,25,29-31]$. Further input parameters can also be imported from an XML configuration file step. The module analyses each land field polygon, tagged with a certain type of vegetation and soil. Therefore, the module was able to find the corresponding biomass yield of the crop on the soil, the possible bioenergy usages and bioenergy conversion coefficient from the XML configuration file. It then calculated the corresponding technical bioenergy energy potential, with the output being exported to a CSV file.

\subsection{Approach to Data Validation}

The biomass yield results of AquaCrop for various crop and soil types were validated by comparison to statistical data. The biomass yield given by AquaCrop is the above-ground value in dry mass (DM), whereas statistical values are typically given in fresh mass, i.e., including average water contents $[23,32]$ and thus requiring conversion into dry mass values. In SimStadt, yields were simulated for three German counties with different climate patterns, under no specific field management, no irrigation, and no shallow ground water available.

The county of Ludwigsburg is located in the centre of Baden-Württemberg, in Germany's south-western corner. It covers an area of $687 \mathrm{~km}^{2}$, with a population of about 550,000 inhabitants. $55 \%$ of the county's land area is agricultural land, and $18 \%$ forest [33]. The county of Dithmarschen in the state of Schleswig-Holstein is bordering the North Sea. Its population of 133,000 is spread over an area of $1428 \mathrm{~km}^{2}$, with $78 \%$ of the county's land area being agricultural land, and 3\% forest [34]. The county of Ilm-Kreis has the land area of $805 \mathrm{~km}^{2}$, among which $43 \%$ is agricultural land and $42 \%$ is forest [35]. The total population in year 2019 is about 106,000 [35].

Thus, Ludwigsburg represents a suburban and densely populated county in Germany's south, whereas Dithmarschen represents a rural county in Germany's north with low forest cover and high agriculture cover, and Ilm-Kreis represents a neither very rural nor (sub)urban county in Germany's hilly and relatively densely forested center. However, both counties use a sizeable share of their land for agriculture and should thus have meaningful bioenergy potentials

Table 4 shows the comparison of yield simulation results with actual yields for selected crops in and the three German counties of Ludwigsburg (south-west), Dithmarschen (north), and Ilm-Kreis (mid-eastern Germany). Only yields on soil types that actually exist in the respective county are compared. As yields vary between location due to a difference in climate, a location-dependent actual yield was introduced to better validate yields in different locations. Actual crop yield data were obtained from the global yield gap atlas (GYGA) [36]. GYGA provides robust estimates of untapped crop production potential on existing farmland, based on current climate data and available soil and water resources globally [37]. In Germany, crop yield data is only available for wheat, maize, and barley. Since barley did not feature in the crop category in Table 1, only yields of rainfed wheat and maize could be compared with modeling results. The actual yield only considered the yield of the harvestable organ, e.g., grain of wheat and maize. Harvest index values, i.e., the ratio between weight of 
harvestable organ and the weight of the whole plant, of $52 \%$ and $47 \%$ for maize and wheat respectively were retrieved from $[38,39]$. Furthermore, it has to be noted that GYGA did not differentiate between spring and winter cereals. The climate data used for validation was the average climate between year 2000 and 2010.

As Table 4 shows, all modeling results lay within the yield range given by GYGA. The difference between yields on different soils of the same crop was highest for winter cereals, with $5.2 t_{D M} /(h a)$ ), while for most crops the yield difference between soils was in the order of $1 t_{\mathrm{DM}} /$ (ha a). In Ludwigsburg county, the actual yield of spring cereal was $15.3 \mathrm{t}_{\mathrm{DM}} /\left(\right.$ ha a), compared with $15.5 \mathrm{t}_{\mathrm{DM}} /($ ha a) based on our model, i.e., a deviation of $1.3 \%$. The modeled yield of spring cereals was even closer to the actual yield for Ilm-Kreis with 16.0 and $16.1 \mathrm{t}_{\mathrm{DM}} /$ (ha a), respectively, i.e., a difference of $0.1 \mathrm{t}_{\mathrm{DM}} /(\mathrm{ha}$ a) or $0.6 \%$. Larger deviations occurred for winter cereal in Ludwigsburg and in Ilm-Kreis, and maize in Ilm-Kreis. The modeled yield of maize in Ilm-Kreis had the largest deviation of $7.4 t_{\mathrm{DM}} /(\mathrm{ha}$ a), or $35 \%$, compared with statistical yield of $21 \mathrm{t}_{\mathrm{DM}} /$ (ha a). Deviation can be explained by the deviation of crop harvest rates and low spatial resolution. No yield data of maize in Dithmarschen was available based on GYGA data, even though [15] shows maize being grown in Dithmarschen.

Table 4. Result of simulated biomass yield in dry mass (DM) on different soils and different climates, and comparison to actual yields for the German counties of Ludwigsburg, Ilm-Kreis, and Dithmarschen. Unit: $\mathrm{t}_{\mathrm{DM}} /($ ha $\mathrm{a})$.

\begin{tabular}{|c|c|c|c|c|c|c|c|c|}
\hline \multirow[b]{2}{*}{ Crop Type } & \multirow[b]{2}{*}{$\begin{array}{l}\text { Minimal } \\
\text { Yield }\end{array}$} & \multirow[b]{2}{*}{$\begin{array}{c}\text { Maximal } \\
\text { Yield }\end{array}$} & \multirow[b]{2}{*}{$\begin{array}{l}\text { Actual } \\
\text { Yield }\end{array}$} & \multicolumn{3}{|c|}{ Simulated Yield } & \multirow[b]{2}{*}{$\begin{array}{c}\text { Average } \\
\text { Simulated Yield }\end{array}$} & \multirow[b]{2}{*}{ Deviation } \\
\hline & & & & $\begin{array}{l}\text { Silty } \\
\text { Clay }\end{array}$ & $\begin{array}{l}\text { Loamy } \\
\text { Silt }\end{array}$ & $\begin{array}{c}\text { Clayish } \\
\text { Silt }\end{array}$ & & \\
\hline \multicolumn{9}{|c|}{ County Ludwigsburg } \\
\hline Spring Cereal & 6.3 & 20.4 & 15.3 & 15.5 & 15.5 & 15.5 & 15.5 & $1.3 \%$ \\
\hline Winter Cereal & 8.4 & 22.8 & 15.3 & 23.2 & 25.4 & 25.3 & 25.3 & $65.4 \%$ \\
\hline Maize & 3.3 & 26.4 & 17.0 & 17.2 & 17.7 & 17.6 & 17.5 & $2.9 \%$ \\
\hline \multicolumn{9}{|c|}{ County Dithmarschen } \\
\hline Spring Cereal & 6.3 & 20.4 & 18.9 & 16.8 & 16.3 & 16.8 & 16.6 & $-12.2 \%$ \\
\hline Winter Cereal & 8.4 & 22.8 & 18.9 & 20.1 & 25.1 & 23.4 & 20.2 & $6.9 \%$ \\
\hline Maize & 3.3 & 26.4 & - & 11.2 & 12.1 & 12.0 & 11.8 & - \\
\hline \multicolumn{9}{|c|}{ County Ilm-Kreis } \\
\hline Spring Cereal & 6.3 & 20.4 & 16.0 & 16.1 & 16.1 & 16.1 & 16.1 & $0.6 \%$ \\
\hline Winter Cereal & 8.4 & 22.8 & 16.0 & 24.4 & 25.2 & 25.2 & 25.2 & $57.5 \%$ \\
\hline Maize & 3.3 & 26.4 & 21.0 & 13.6 & 13.7 & 13.7 & 13.7 & $34.8 \%$ \\
\hline
\end{tabular}

Differences between simulated and actual yields can furthermore be explained by the biomass modeling process: while simulated yields were the accumulated yields over the growing periods, including all the parts above ground and without land management and fertilization, any form of land management to remove, e.g., unwanted parts of plants during the growing period would change the actual yield.

A validation of modeled bioenergy potentials on a subnational and substrate level with actual bioenergy usage levels was inherently limited, since for example information on in/exports of bioenergy as primary or secondary energy carriers into and out of a (in our case) county is typically not available, and technical potentials are rarely fully exploited for a variety of reasons. On a national level in Germany, few studies have assessed aggregated bioenergy potentials in long-term scenarios $[30,40,41]$. Generally, bioenergy potentials vary depending on natural protection regulation, which impacts the available land area for energy crops, yielding for example values from 543, without consideration of energy crops, to $1425 \mathrm{PJ} / \mathrm{a}$ in a "highest probability" scenario, to $1900 \mathrm{PJ} / \mathrm{a}$ under an "optimal land use" scenario [41]. As the model presented here considered the total natural land use area, the total natural vegetation cover area of Germany, 298,065 ha, would be applied to derive energy yields on a national level. Given that, the average technical bioenergy yield should be between 5.1 and $17.7 \mathrm{MWh} /(\mathrm{ha}$ a) based on above-mentioned potentials [41], with the energy yield of $13.3 \mathrm{MWh} /($ ha a) as the most realistic considering the constrains. As Table 5 shows, the model in this paper yielded the total bioenergy 
technical potentials between 10.7 and $12.0 \mathrm{GWh} /$ ha in all three counties, which fit the result of other studies quite well.

Table 5. Technical bioenergy potential yield in three counties in Germany.

\begin{tabular}{ccccc}
\hline Parameter & Unit & Ludwigsburg & Dithmarschen & Ilm-Kreis \\
\hline Total area & $(\mathrm{ha})$ & 50,302 & 124,108 & 74,451 \\
Total bioenergy potential & $(\mathrm{GWh})$ & 647 & 1346 & 796 \\
Bioenergy energy yield & $(\mathrm{GWh} / \mathrm{ha})$ & 12.0 & 10.8 & 10.7 \\
\hline
\end{tabular}

\subsection{Scenarios Setting}

For each of the counties of Ludwigsburg and Dithmarschen, one base case and three sensitivity scenarios were defined to quantify the influence of (i) climate change, (ii) priority setting on the forms of bioenergy produced from the available biomass resources, and (iii) use of irrigation on energy yields. Hereby, the aim is not to come up with comprehensive and realistic future scenarios, but rather to test whether the proposed modeling approach reacts reasonably to parameter changes.

Table 6 gives an overview of the four scenarios. Here, only changes with regards to the base case are listed, with all other parameters remaining the same as in the base case (Table A5). The values from Table A5 were applied in the base case while Table A6 gives the share of various secondary energy carriers produced from the most important energy crops in the base case scenario (Germany, 2018 data) [29]. Table 7 gives the key parameters of climate at current state (average between 2000 and 2010) and in forecasted case 2050. It has to be noted that beyond the crops listed in Table A6, it is possible to for example produce bioethanol from plants rich in starch, e.g., potato. However almost all the potato for non-food use goes to material production for industrial starch [29]. Furthermore, residue of energy crops is mostly directly used as solid fuel, without any further conversion, while about $40 \%$ of maize silage residue is used for biogas production [29,31] (the other maize residue products are assumed to become solid fuel).

Table 6. Base case and sensitivity scenarios.

\begin{tabular}{ll}
\hline Scenario Name & Explanation \\
\hline Base case & Values of Tables A5 and A6 in Appendix D applied [23] \\
\hline Climate 2050 & $\begin{array}{l}\text { Climate forecast data in 2050 including temperature, precipitation, and } \mathrm{CO}_{2} \\
\text { concentration change. The key parameters of climate situation in both counties are } \\
\text { listed in Table 7. }\end{array}$ \\
\hline $\begin{array}{l}\text { Optimization for } \\
\text { fuel consumption }\end{array}$ & $\begin{array}{l}\text { If an energy crop can be a source for biodiesel and bioethanol, all of its yield will be } \\
\text { used to this end. If the crop cannot be used for the production of this biofuel carrier, } \\
\text { it would follow the same distribution as given in Table A6 }\end{array}$ \\
\hline Water-energy nexus & $\begin{array}{l}\text { The impact of different irrigation levels on bioenergy potential. Water stress is set at } \\
\text { different levels in percentage to simulate water demand under different irrigation } \\
\text { conditions. The irrigation water demand is the minimum amount of water that has } \\
\text { to remain in the root zone throughout the growing cycle, and as such the water stress } \\
\text { that is allowed in the season. }\end{array}$ \\
\hline
\end{tabular}

\subsection{Ludwigsburg and Dithmarschen Test Cases}

Land coverages and populations data for Ludwigsburg and Dithmarschen were already introduced in Section 2.6.

As for Ludwigsburg, it has set itself a goal (in 2013) of reducing greenhouse gas emissions by 90\% until 2050 through increased energy efficiency and increasing the share renewable energy sources, e.g., through using biomass for local heat and power generation [43]. The extrapolated 2018 end energy demand (electricity, heating, gasoline, and diesel) in Ludwigsburg is $8506 \mathrm{GWh}$, with diesel and gasoline accounting for $106 \mathrm{GWh}$ and $58 \mathrm{GWh}$, respectively [43,44]. The extrapolated end energy 
demand in Dithmarschen in 2018 was 5714 GWh. Among this, end energy demand for transport was $971 \mathrm{GWh}$, or $11 \%$ of the total for diesel and $6 \%$ for petrol $[45,46]$.

Table 7. Temperature, precipitation, and $\mathrm{CO}_{2}$ concentration levels in the three counties, average climate between 2000 and 2010 and 2050. The climate data is generated by Meteonorm [42].

\begin{tabular}{cccccc}
\hline & Unit & \multicolumn{2}{c}{ Ludwigsburg } & \multicolumn{2}{c}{ Dithmarschen } \\
\hline Climate & - & $\mathbf{2 0 0 0 - 2 0 1 0}$ & $\mathbf{2 0 5 0}$ & $\mathbf{2 0 0 0 - 2 0 1 0}$ & $\mathbf{2 0 5 0}$ \\
\hline Yearly average temperature [42] & $\left({ }^{\circ} \mathrm{C}\right)$ & 10.1 & 10.8 & 9.5 & 10.1 \\
Precipitation [42] & $(\mathrm{mm} / \mathrm{a})$ & 729 & 716 & 794 & 839 \\
$\mathrm{CO}_{2}$ concentration [24] & $(\mathrm{ppm})$ & 409 & 469 & Same as Ludwigsburg \\
\hline
\end{tabular}

\section{Results}

\subsection{The Impact of Climate Change}

Changes in ambient temperature, precipitation, and atmospheric $\mathrm{CO}_{2}$ concentration (see Table 7), allow one to assess the impact of climate change on crop and by this bioenergy yields. Climate change will increase average temperatures in all three regions, by about $0.5{ }^{\circ} \mathrm{C}$ until 2050 compared to the average value between 2000 and 2010, while the change in precipitation patterns was mixed: yearly precipitation levels were expected to increase from 794 to $839 \mathrm{~mm}$ in Dithmarschen, and from 570 to $590 \mathrm{~mm}$ in Ilm-Kreis, while they were expected to fall from 729 to $716 \mathrm{~mm}$ in Ludwigsburg.

Figure 3 shows how various crops react to changes in these parameters as indicated in Table 6 for Ludwigsburg and Dithmarschen. The spans of black lines indicate different yields on different soil types, while the points show the median value of crops yield under the average climate between 2000 and 2010 and climate in 2050. These developments would imply changes of $\pm 0.2 t_{\mathrm{DM}} /(\mathrm{ha}$ a) by 2050 for most crops compared with current yields, except for maize, with around $1.5 \mathrm{t}_{\mathrm{DM}} /(\mathrm{ha}$ a) higher yields in Dithmarschen. In fact, only the change in climate until 2050 might make maize cultivation economically attractive in Dithmarschen. Taking these temperature and precipitation changes into account, our model still gives plausible results. In both counties, the yield of rapeseed increased between $11 \%$ and $13 \%$. The specific yield of maize in Dithmarschen shows an increase of $35 \%$, as the region moved into a climatic zone favorable to maize cultivation; however, in Ludwigsburg, maize yields decreased by $12 \%$. Opposite to that, grass would produce $21 \%$ less biomass in Dithmarschen but $8 \%$ more in Ludwigsburg. This can be explained by grass tending to be in favor of moderate cool and humid climate. In both counties, yields of spring cereal, winter cereal, sugar beet, and potato changed by less than $\pm 3 \%$ until 2050 .

As Appendix E shows, the total bioenergy potential increased by only $0.2 \%$, from 646 to $648 \mathrm{GWh} / \mathrm{a}$, due to climate change in Ludwigsburg. Therein, bioethanol and solid fuel potentials do not change at all, while the biodiesel potential increased by $13 \%$, from 1.5 to $1.7 \mathrm{GWh} / \mathrm{a}$, which could be explained by the fact that the yield of rapeseed, being the main source for biodiesel (see Table A6), was positively affected by a temperature increase from 10.1 to $10.8^{\circ} \mathrm{C}$ as expected for Ludwigsburg until 2050. In Dithmarschen, the technical energy potential changed by $4 \%$, from 1327 to $1381 \mathrm{GWh} / \mathrm{a}$ by $4 \%$. Half of the increase could be explained by the increase in the yield of maize, leading to higher biogas yields. Additionally, higher yields of SRC resulted in higher solid fuel potentials. In both regions, the potentials of energy wood from forest are generally limited as (i) less than $4 \%$ of forest biomass can be harvested annually (see Table A5), (ii) only about $25 \%$ (see Table A5) of harvested wood biomass was directed to energetic uses, and (iii) forests were not the dominant type of land cover type in both regions, with shares of $33 \%$ and 3\% in Ludwigsburg and Dithmarschen, respectively. 


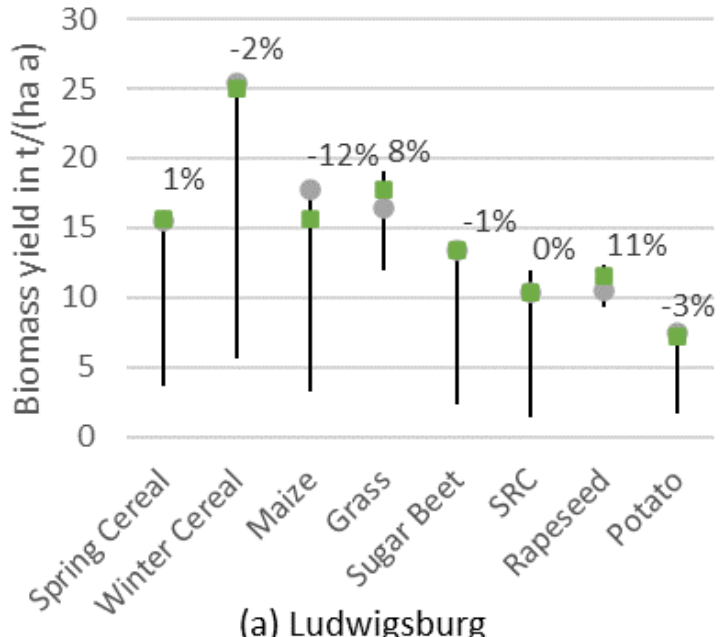

(a) Ludwigsburg

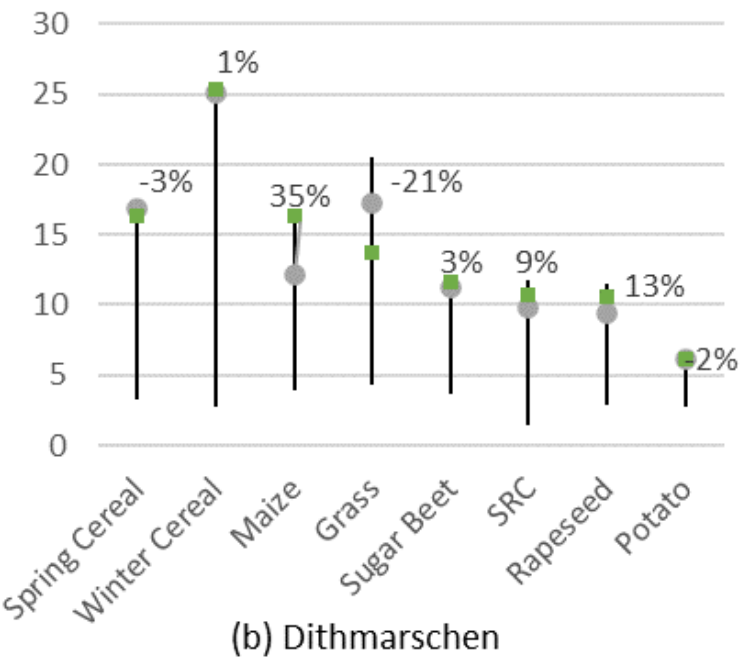

- Median value, current climate

- Median value, climate in 2050

Figure 3. Above-ground biomass yields and their changes in percentage of crops from simulation result under current climate and forecasted climate in 2050 in (a) Ludwigsburg and in (b) Dithmarschen (right). The minus represents the decrement of median value between two climate scenarios.

\subsection{Optimizing Biofuel for Tranportation Sector}

Biofuels have been required to account for at least $2 \%$ of the total transportation fuels used in EU member states since 2005. With the Renewable Energy Directive 2018/2001 (RED II), adopted in December 2018, the EU is continuing the political framework for the use of renewable energy sources in the transport sector for the period from 2021 to 2030 [47], while first-generation bioethanol, i.e., ethanol from agricultural crops, will be phased out until 2030. According to [48], sugarcane ethanol will no longer appear in the mix from 2025, as straw ethanol is considered the most attractive unrestricted non-food and non-feed-based option for gasoline. In Germany, the additional introduction of a biofuel quota in 2007 required oil companies to ensure that $4.4 \%$ of diesel sales are made of biodiesel. In addition, they needed to ensure that $1.2 \%$ (from 2008, $2 \%$; from 2009, 2.8\%; and from $2010,3.6 \%$ ) of the sales of motor fuel originate from biofuels [49]. In a scenario that optimizes biofuels for transportation, all energy crops that can be converted into biofuels (biodiesel and bioethanol) were used to $100 \%$ for that purpose. In this scenario, 1st generation bioethanol is still considered as a source for transportation in the short term and can be produced from grains, maize, sugar beet, potato, and SRC, while biodiesel is produced from rapeseed. The climate data is unchanged as in the base case with average climate between 2000 and 2010.

As Figure 4 shows, bioethanol potentials increased from 48.1 to $98.5 \mathrm{GWh} / \mathrm{a}$, i.e., by $105 \%$, in Ludwigsburg. Since crops used for bioethanol could alternatively be used for biogas production, biogas potentials decreased by $62 \%$. Similarly, in Dithmarschen the amount of bioethanol potential increased by $100 \%$. However, the technical potential of biodiesel in both counties stayed unchanged.

Differences in total technical bioenergy potentials stem from different conversion efficiencies from biomass to biogas and bioethanol, respectively, as indicated in Table 8: for instance, for cereals, maize and SRC, a conversion to biogas yields 4-18 percentage points higher energy in the secondary energy carrier than in the case of bioethanol. The actual use of maize as an energy crop (see Table A6) also prioritizes for bioethanol production, regardless of the fact that biogas production would be more effective. In case of being used as food feedstock, however, maize silage is used for biogas production [29]. 


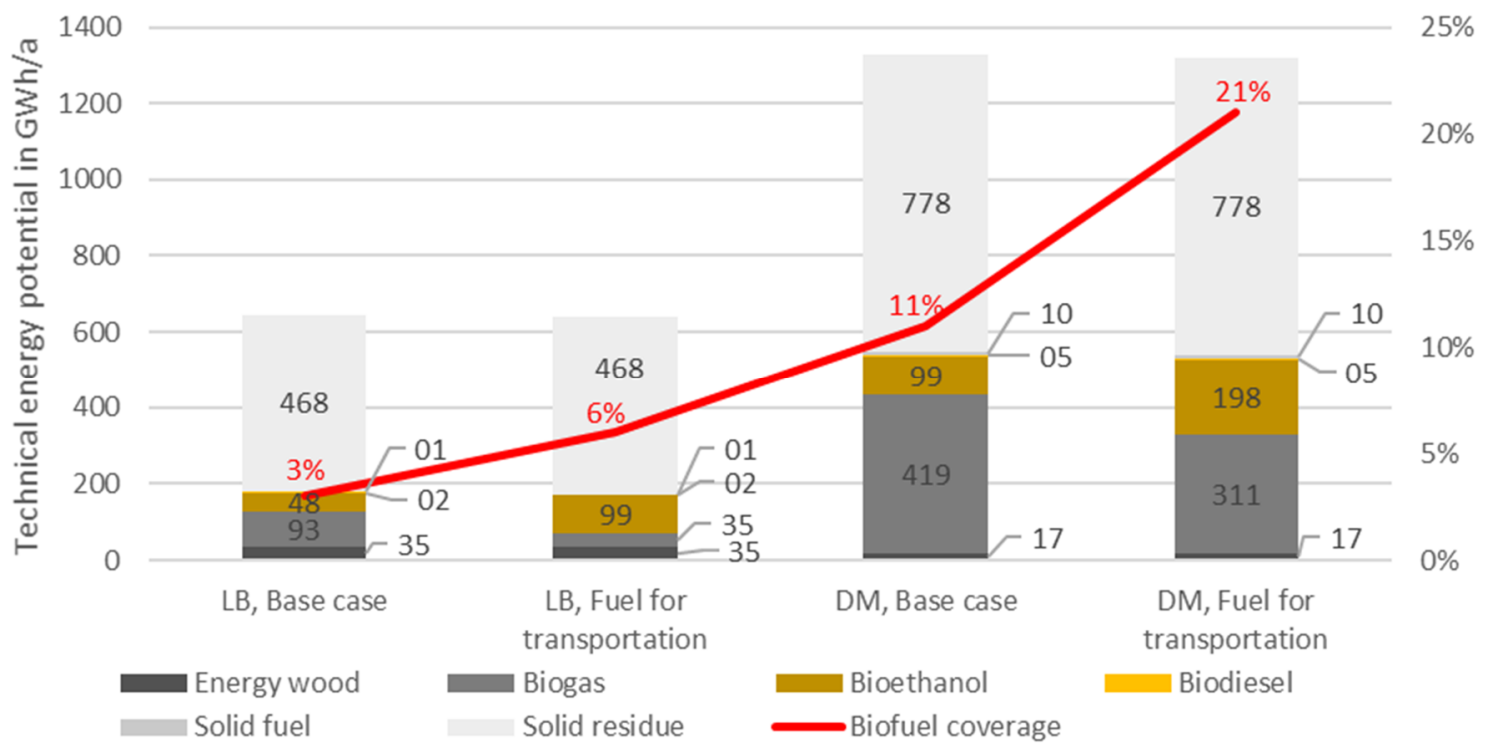

Figure 4. Technical biofuel potential and the transportation fuel demand covered by biofuel of base case and biofuel preferred case in Ludwigsburg and Dithmarschen.

Table 8. Typical conversion efficiency to bioethanol and biogas of crops.

\begin{tabular}{lcc}
\hline \multicolumn{1}{c}{ Crop } & Conversion Efficiency to Biogas ${ }^{\mathbf{1 , 2}}$ & Conversion Efficiency to Bioethanol $^{\mathbf{3}}$ \\
\hline Cereal & $54 \%$ & $46 \%$ \\
Maize & $62 \%$ & $44 \%$ \\
Sugar Beet & $68 \%$ & $75 \%$ \\
Short Rotation Coppice & $48 \%$ & $44 \%$ \\
Potato & $58 \%$ & $60 \%$ \\
\hline
\end{tabular}

Data collected and adapted from ${ }^{1}$ Faustzahlen für die Landwirtschaft, pp. 938-940; ${ }^{2}$ Bayerisches Staatsministerium für Ernährung, Landwirtschaft und Forsten, Biogasausbeuten-Datenbank; ${ }^{3}$ Flaig, Holger, and Hans Mohr, eds. Energie aus Biomasse, p. 337.

Next to conversion efficiencies, a decisive factor is the demand for certain types of biofuel. In 2018, Ludwigsburg county used 1722 GWh of diesel and 997 GWh of gasoline for transportation [43]. In the base case, if all bioethanol and biodiesel had been used for transportation, biofuels would have covered $3 \%$ of the total fuel demand, while biofuels could have covered $6 \%$ of the fuel consumption in the scenario prioritizing biodiesel and bioethanol production. In Dithmarschen $106 \mathrm{GWh}$ of diesel and 58 GWh of gasoline were consumed in 2017. Being more rural than Ludwigsburg, bioethanol and biodiesel could have covered $11 \%$ of the total fuel demand in the base case and $21 \%$ in the scenario prioritizing biodiesel and bioethanol production.

\subsection{The Impact of Irrigation}

In a fourth scenario, external irrigation is applied in addition to natural precipitation. A crop's irrigation demand is determined by the minimal amount of external water that has to remain in the root zone throughout the growing cycle, so that the given water stress is maintained in the growing season. Water stress levels from $10 \%$ to $90 \%$, in $10 \%$ steps, and from $92 \%$ to $98 \%$ in $2 \%$ steps, were set to simulate water demand under different irrigation conditions. The higher the water stress level, the less water is allowed to stay in the soil. Adequate or more water in the soil (lower actual water stress level than set value) brought by natural rainfall is allowed. In this case no external irrigation is needed.

Figure 5 shows the relation between relative technical bioenergy yield and the amount of irrigation. The relative technical bioenergy yield is defined as the total technical bioenergy yield under current water stress level with the total technical bioenergy yield at a water stress level of $0 \%$ (adequate water during growing period). As Figure 4 shows, irrigation led to a technical bioenergy potential increased 
of $1 \%$ in Ludwigsburg and $4 \%$ in Dithmarschen even with the minimal amount of irrigation to keep the water stress level at $98 \%$. The two points at origin represent the base case-without irrigation. We argued that the most left points in both cases were the irrigation saturation points at about $100 \mathrm{~m}^{3} /$ (ha a) in Ludwigsburg and $200 \mathrm{~m}^{3} /($ ha a) in Dithmarschen.

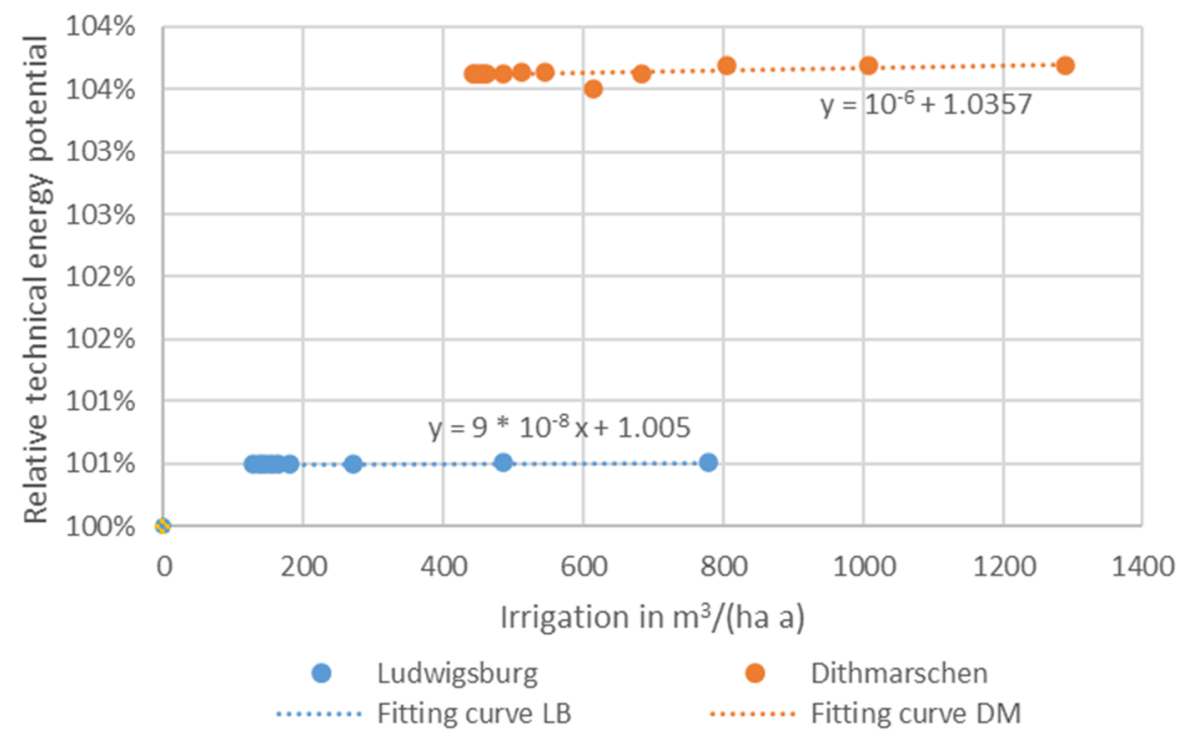

Figure 5. Sensitivity analysis of between relative technical yield and irrigation amount per hector in Ludwigsburg and Dithmarschen.

The relative indifference of energy potentials to irrigation can be explained by the relative biomass. Relative biomass is the ratio between the actual biomass amount and the ideal reference case (no water stress, no soil fertility, no soil salinity stress, and no weed infestation). Here, we discarded salinity and weed infestation in the first place, so the reference only presented the ideal yield with enough water available. Table 9 shows relative biomass without irrigation in the base case climate for both Ludwigsburg and Dithmarschen. It can be seen that some crops (spring cereal, maize, sugar beet, and potato) already yield (almost) 100\% of biomass without irrigation, while other crops, e.g., grass and SRC, required additional water supply to reach a $100 \%$ yield. Here, soil types also influenced biomass yields. For most crops, and regardless of soil types, applying irrigation can only increase biomass yields by less than $7 \%$, thus contributing little to the overall technical bioenergy potential. To be more detailed, from a bioenergy perspective, irrigation should for example only by applied to crops on silty clay soil and SRC on clayish silt in Ludwigsburg.

Table 9. Relative biomass without irrigation under current climate in Ludwigsburg (LB) and Dithmarschen (DM).

\begin{tabular}{ccccccc}
\hline \multirow{2}{*}{ Crop } & \multicolumn{5}{c}{ Relative Biomass } \\
\cline { 2 - 7 } & \multicolumn{2}{c}{ Silty Clay } & \multicolumn{2}{c}{ Loamy Silt } & \multicolumn{2}{c}{ Clayish Silt } \\
\cline { 2 - 7 } & LB & DM & LB & DM & LB & DM \\
\hline Spring Cereal & $99 \%$ & $99 \%$ & $99 \%$ & $99 \%$ & $99 \%$ & $99 \%$ \\
Winter Cereal & $92 \%$ & $80 \%$ & $100 \%$ & $100 \%$ & $100 \%$ & $93 \%$ \\
Maize & $100 \%$ & $91 \%$ & $100 \%$ & $100 \%$ & $100 \%$ & $98 \%$ \\
Grass & $83 \%$ & $85 \%$ & $91 \%$ & $94 \%$ & $93 \%$ & $94 \%$ \\
Sugar Beet & $98 \%$ & $100 \%$ & $100 \%$ & $100 \%$ & $100 \%$ & $100 \%$ \\
SRC & $48 \%$ & $57 \%$ & $99 \%$ & $97 \%$ & $73 \%$ & $96 \%$ \\
Rapeseed & $89 \%$ & $85 \%$ & $93 \%$ & $94 \%$ & $93 \%$ & $91 \%$ \\
Potato & $100 \%$ & $100 \%$ & $100 \%$ & $100 \%$ & $100 \%$ & $100 \%$ \\
\hline
\end{tabular}




\section{Discussion}

This paper proposed a new workflow that allows one to assess technical bioenergy potentials at the regional level in high resolution, considering local climates and soil conditions, and crop distributions. It builds on commonly available input data such as digital landscape models. In the newly established workflow the advantages of two tools are combined: SimStadt assesses regional energy potentials and demands primarily based on geoinformatic data, and AquaCrop simulates biomass yields and water demands based on soil types, crop types, and climate situations [50]. Integrating AquaCrop enables more accurate bioenergy potential calculations than merely applying average statistical yields that disregard local environmental parameters such as climate and soil.

Yield modeling results were compared with actual yield from GYGA, with deviations of usually less than $1.3 \%$. On the aggregated level, bioenergy potential studies for Germany have shown average biomass technical energy yields of between 5.1 and $17.7 \mathrm{MWh} /(\mathrm{ha}$ a), with most realistic yields of 13.3 MWh/(ha a) considering existing constrains. The newly established workflow yields values between 10.7 and $12.0 \mathrm{MWh} /($ ha a), thus in line with [20,40,41]. For the case studies of Ludwigsburg and Dithmarschen, technical bioenergy potentials were calculated as $465 \mathrm{GWh} / \mathrm{a}$ and $1327 \mathrm{GWh} / \mathrm{a}$ respectively, which would be $5 \%$ and $23 \%$ of the total extrapolated 2018 and 2017 end energy demands. As a comparison around 3.9\% of electricity is covered by biomass in county Ludwigsburg in 2014 [43]; while $6.6 \%$ of the thermal energy demand is covered by biomass in Dithmarschen in 2010 [45]. It has to be noticed that the biomass in the reports $[43,45]$ does not necessarily come from local sources. The results show that at least for the case of Dithmarschen, the more rural county of the two, there might still be a substantial untapped potential in local biomass utilization.

Climate change will lead to a $0.2 \%$ increase in the technical bioenergy potential in Ludwigsburg until 2050, and a $4 \%$ increase in Dithmarschen according to the result of this paper. For Dithmarschen, the increment of temperature from climate condition favors the maize; in Ludwigsburg a very slight increase of biomass potential is driven by two opposing effects: the temperature increment is favorable however reduced precipitation is detrimental to biomass yields, consistent with results in [51].

By directing bioenergy production to bioethanol and biodiesel for transportation, bioethanol productions could almost double in both regions covering $6 \%$ and $21 \%$ of the total transportation energy consumption in Ludwigsburg and in Dithmarschen respectively. Under the current application case, solid fuel or biogas could be used in a combined heat and power unit (CHP), while bioethanol and biodiesel play a more important role in transportation until 2030. However, with the introduction of act RED II, bioethanol and biodiesel production from crop is not allowed beyond 2030. While biogas is expected to be the dominate fuel for non-electric transportation until 2050 [52]. Thus, the local energy planner should also consider the policy restrains to make policies to direct biomass use.

With regards to irrigation, our model shows that yield gains were at best modest for the most important relevant crops in the studied regions: in Ludwigsburg $128 \mathrm{~m}^{3} /$ ha of irrigation water only brought the total technical energy potential increment of less than $1 \%$ (See Figure 5). The benefits seemed more significant in Dithmarschen-a $4 \%$ total technical energy potential increment with $441 \mathrm{~m}^{3} /$ ha irrigation (see Figure 5). Different amounts of external irrigation to keep the water stress level between $10 \%$ and $98 \%$ did not bring significant gain among them. Most crops had close to $100 \%$ relative biomass rate in both regions, which means crop yields could not be improved through additional irrigation. This is in accordance to the presented simulation results showing limited benefits from irrigation. Irrigation should thus only be applied selectively, e.g., on SRC on silty clay in Ludwigsburg, where the relative biomass rate could be increased by $52 \%$.

There are limitations to the method in this paper: (i) The availability of reasonably detailed soil and crop maps determined the applicability, even though the method itself is generic and globally applicable. So far, the bioenergy potential in any region only in Germany can be assessed. (ii) For forests and orchards, static biomass yield values from the literature were assigned, rather than the in-depth modeling applied to crops such as cereals or maize. As forest growing cycles span multiple years and yields also depend on groundwater levels, rather than merely on precipitation. A model that assesses 
forest similar to crops would be much more complex. Therefore, the influence from precipitation and irrigation is only restricted to crop. (iii) The secondary energy carriers that might be produced do not (yet) include hydrogen from biomass. Even though it is now widely recognized that considerable amounts of hydrogen can be produced from renewable sources through biological processes such as bacterial hydrogen fermentation, at the present stage of development of hydrogen fermentation technology has not been applied at the industrial-scale with economic advantage [53]. Nevertheless, the presented method can and should be extended to cover hydrogen potential analysis in order to confront with the biofuel development trend.

\section{Conclusions}

The methodology and workflow presented in this paper present a novel, generic method to evaluate bioenergy potentials for any region with good accuracy, by simultaneously considering constraints of water availability, climate, and soil. Furthermore, these bioenergy potentials can compare other RES to potentials and local heating, cooling, or electricity demands within one simulation platform based on a consistent set of input data that is moreover relatively accessible for many regions. The new method does not, however, aim to provide a highly accurate assessment of regional bioenergy potentials based on customized data for a specific region.

In the context of the water-energy nexus, our research extends an energy-centric modeling environment to water-related aspects, namely crop transpiration and potential irrigation benefits or requirements. A combination with the urban residential and non-residential water demand simulation workflow presented in [54], which also bases on similar input data, allows one to study the nexus between bioenergy, crop irrigation, and urban water consumption in the regional context. With the newly established biomass, roof PV, electricity, and heating demand workflow [27] in place, the modeling environment SimStadt can now assess regional renewable energy balances with the constraint of water and climate in regions without rich wind, ground-based PV, or hydro potentials. As the next steps, (i) a workflow similar to the presented bioenergy one will be developed for wind power. (ii) The nexus will be extended to food-energy nexus, by, e.g., (a) assessing local balances between food-use and energy-use of crops to fulfill local demands and to meet strategic goals of emission reduction by regionalization of food supply [55]. (b) Investigating the impact of diet change, e.g., more plant-based diets, on local food and energy potentials will be carried out.

Author Contributions: Conceptualization: K.B.; Data curation: K.B., R.P.; Investigation: K.B.; Methodology: K.B.; Software: K.B.; Validation: K.B.; Formal analysis: K.B.; Visualization: R.P., K.B.; Supervision: B.S., D.T., V.C.; Writing-original draft: K.B.; Writing—review and editing: B.S., D.T., R.P. All authors have read and agreed to the published version of the manuscript.

Funding: This paper is part of the project IN-SOURCE (INtegrated analysis and modeling for the management of sustainable urban FEW ResSOURCEs). This research was funded from the European Union's Horizon 2020 research and innovation program under grant agreement No 730254.

Acknowledgments: This paper extends the paper "GIS-Based Assessment of Regional Biomass Potentials at the Example of Two Counties in Germany" published in the e-EUBCE 2020 conference proceeding. Food and Agriculture Organization of the United Nations (FAO) is the source and copyright holder of the biomass yield and water simulation software AquaCrop. The CityGML maps of Dithmarschen and Ilm-Kreis are required in the project EnSys-LE (03ET4061B) funded by Federal Ministry for Economic Affairs and Energy.

Conflicts of Interest: The authors declare no conflict of interest.

\section{Abbreviations}

$\begin{array}{ll}\text { Abbreviations } & \text { Explanation } \\ \text { GIS } & \text { Geographic information system } \\ \text { RES } & \text { Renewable energy sources } \\ \text { FWE } & \text { Food-Water-Energy } \\ \text { DLM } & \text { Digital Landscape Model } \\ \text { ALKIS } & \text { Germany's Official Real Property Cadastre Information System }\end{array}$




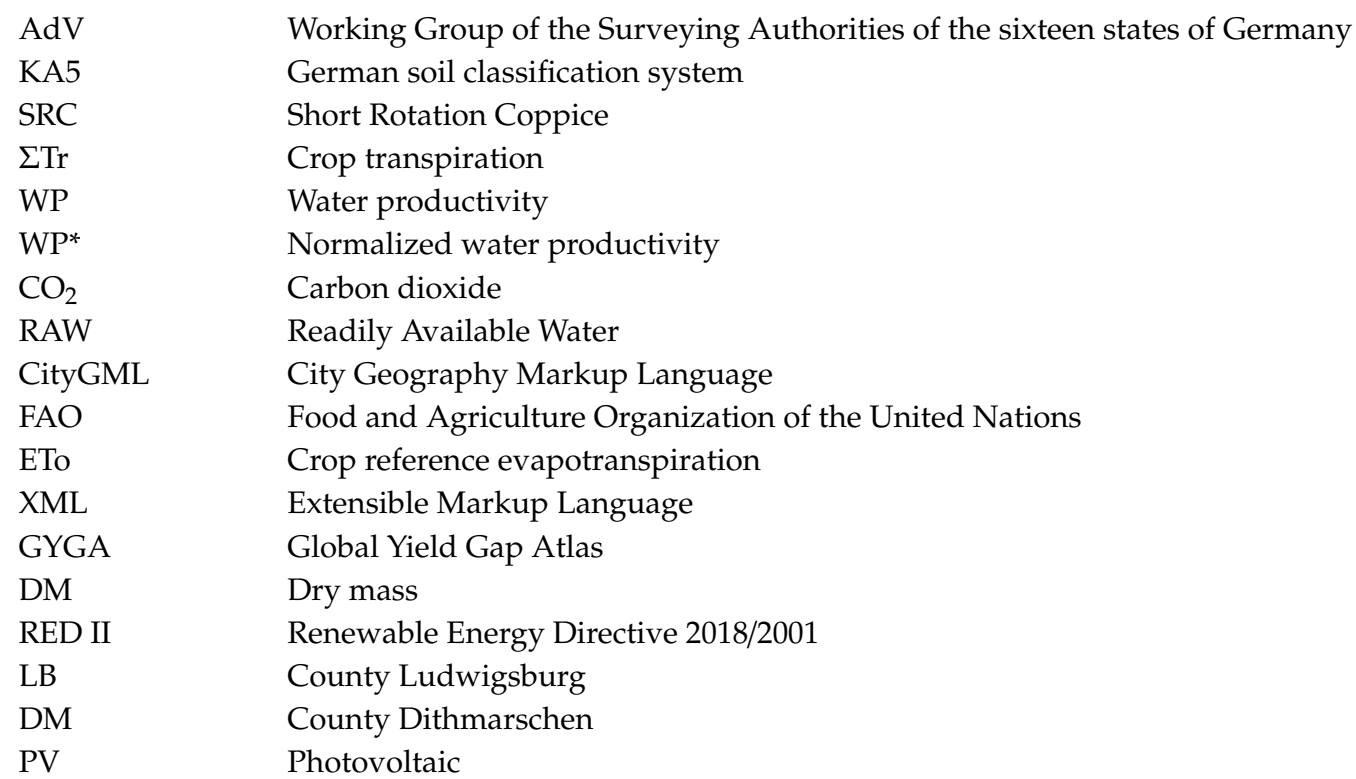

\section{Appendix A}

Table A1. Soil type group according to German soil classification system [19].

\begin{tabular}{ll}
\hline Soil Surface not Sealed & Soil Surface Sealed \\
\hline $\begin{array}{l}\text { Pure sands } \\
\text { Silty sands }\end{array}$ & City center areas (surface $>70 \%$ sealed) \\
\hline $\begin{array}{l}\text { Normal clays } \\
\text { Loamy silt }\end{array}$ & Anthropogenically embossed surfaces (surface $30-70 \%$ sealed) \\
\hline $\begin{array}{l}\text { Silt clays } \\
\text { Loamy sands }\end{array}$ & Technogenic ally designed areas, including mining areas \\
\hline $\begin{array}{l}\text { Sand Loams } \\
\text { Clay Loams } \\
\text { Clay silt } \\
\text { Moors } \\
\text { Tidal flats }\end{array}$ & \\
\hline
\end{tabular}

\section{Appendix B}

$$
P_{\text {theoretical }}=\sum A_{\text {vegetation }, i} \cdot Y_{\text {vegetation }, i} \cdot H_{u, i}
$$

$P_{\text {theoretical }}$ is the theoretical energy potential of a specific land field in GJ/ha·a. $i$ is the crop type. $A_{\text {vegetation }}$ is the area in ha of the vegetation type. $Y_{\text {vegetation }}$ is the dry matter production yield of a specific vegetation type in $\mathrm{t} /(\mathrm{ha} \cdot \mathrm{a}) . H_{u}$ is the calorific value in gigajoules per tonne $\left[\mathrm{GJ} / t_{\text {lutro }}\right]$.

$$
P_{\text {wood }}=\sum A_{\text {forest }, i} \cdot \operatorname{Efm}_{i} E f m \cdot n_{f, \text { energy }, i} \cdot n_{f, c f, i} \cdot p_{i} p \cdot H_{u, i}
$$

where $P_{\text {wood }}$ is the forest fuel potential in gigajoules per year [GJ/a]. $A_{\text {forest }}$ stands for the area of the individual forest type (broad-leaf, coniferous forest, the mix of both) in hectares (ha). Efm is the harvest cubic metres per hectare per year $\left[\mathrm{m}^{3} / \mathrm{ha} / \mathrm{a}\right]$. One harvest cubic metre of wood is equivalent to one cubic metre of solid wood stored without gaps in the stratification. $n_{f, c f}$ is the harvest share. $n_{f, \text { energy }}$ is 
the share of energetic uses. $p$ is the conversion factor for firewood $\left[t_{l u t r o} / \mathrm{m}^{3}\right] . H_{u}$ is the calorific value in gigajoules per tonne $\left[\mathrm{GJ} / t_{\text {lutro }}\right]$.

$$
P_{\text {biogas }, \mathrm{GL} / \mathrm{OM}}=\sum A_{i} \cdot E_{\text {crop }, i} \cdot T_{i} \cdot \mathrm{OTS} S_{i} \cdot E_{\mathrm{CH} 4, \mathrm{i}} \cdot n_{\text {energy }, \mathrm{i}} \cdot H_{u, i}
$$

where $P_{\text {biogas, } \frac{G L}{O M}}$ is the annual biogas fuel potential [GJ/a]. $i$ is the crop type. $A_{i}$ is the area of the crop that can be as the source of biogas production in hectares (ha), $E_{\text {crop }}$ is the crop harvest yield of fresh mass of each crops [kg/ha.a], TS and $o T S$ are its dry mass rate and organic dry mass rate, and $E_{\mathrm{CH} 4, \mathrm{i}}$ is its methane yield [ $1 / \mathrm{kg}$ oTS]. $n_{\text {energy }, i}$ is the share of actual energetic use per crop, and $H_{u}$ is the calorific value of methane in gigajoules per tonne $\left[\mathrm{GJ} / \mathrm{l} \mathrm{CH}_{4}\right]$.

$$
P_{\text {biodiesel }}=\sum A_{\text {biodiesel }, i} \cdot P_{\text {theoretical }, i} \cdot C_{\text {biodiesel }, i},
$$

where $P_{V O}$ is the fuel potential from rapeseed cultivation for vegetable oil production [GJ/a]. $A_{\text {biodiesel }}$ is the area of the area of biodiesel production crops (rapeseed). $P_{\text {Primary }}$ is the theoretical yield of the crop in $\mathrm{GJ} /\left(\right.$ ha a), $C_{\text {biodiesel }}$ is the conversion efficiency from dry raw mass to biodiesel.

$$
P_{\text {ethanol }}=\sum A_{\text {ethanol }, i} \cdot P_{\text {theoretical }, i} \cdot C_{\text {ethanol }, i}
$$

where $P_{\text {ethanol }}$ is the fuel potential from energy crops for ethanol production [GJ/a], $A_{\text {ethanol }}$ is the area of the area of bioethanol production crops (sugar beet, grain maize and cereals), and $C_{\text {energy }}$ is the ethanol conversion factor from dry raw mass. $P_{\text {Primary }}$ is the theoretical yield of the crop in GJ/(ha a).

$$
P_{\text {residue }}=\sum A_{i} \cdot Y_{i} \cdot C_{\text {residue, }, i} \cdot T S_{i} \cdot n_{\text {energy }, i} \cdot H_{u, i}
$$

where $P_{\text {residue }}$ is the fuel potential of residues as solid fuels in gigajoules per year in GJ/a, $A$ is the area of individual object types in ha, $\mathrm{Y}$ is the dry matter production yield of a specific vegetation type in

\begin{tabular}{|c|c|c|c|c|c|c|}
\hline Potential & Parameter & Unit & Winter Cereal & Spring Cereal & Maize & Grass \\
\hline \multirow{3}{*}{ Theoretical potential } & Wet mass range ${ }^{6}$ & $\mathrm{t} / \mathrm{ha} \mathrm{a}$ & $9.5-20$ & $8.0-17$ & $10.0-22.0$ & $9.0-18.8$ \\
\hline & Water content ${ }^{6}$ & $\%$ & 15 & 15 & 67 & 15 \\
\hline & Heating value $4,5,8$ & $\mathrm{MJ} / \mathrm{kg}$ & 17.1 & 17.1 & 17.1 & 16.5 \\
\hline \multirow[b]{2}{*}{ Biogas } & $\begin{array}{l}\text { oTS Organic dry mass of } \\
\text { dry mass } 7\end{array}$ & $\%$ & 94 & 95 & 95 & 88 \\
\hline & Biogas yield $^{7}$ & 1_N/kg oTS & 520 & 520 & 600 & 560 \\
\hline \multirow{2}{*}{$\begin{array}{l}\text { Bioethanol } \\
\text { Biodiesel }\end{array}$} & Conversion efficiency $^{3}$ & GJ/GJ_Primary & 0.5 & 0.5 & 0.4 & - \\
\hline & Conversion efficiency ${ }^{3}$ & GJ/GJ_Primary & & & & \\
\hline \multirow{2}{*}{ Residue } & Yield range $^{1,2}$ & t FM/(ha a) & $3.5-9.4$ & $3.5-9.4$ & $4.2-10$ & $4.2-26$ \\
\hline & Residue yield factor & $\begin{array}{l}t \text { _residue FM/ } \\
t \text { biomass FM }\end{array}$ & 0.4 & 0.4 & 0.4 & 1.0 \\
\hline
\end{tabular}
$\mathrm{t} /$ (ha. a), $C_{\text {residue }}$ is the residue yield in wet mass per total yield in wet mass, TS is the dry mass rate, $n_{\text {energy }}$ is the percentage of energy usage of residue, and $H_{u}$ is the heat value in gigajoule per kilogram.

Table A2. Biomass potential yield factors of most relevant types of vegetation in Germany. 
Table A2. Cont.

\begin{tabular}{|c|c|c|c|c|c|c|}
\hline Potential & Parameter & Unit & Sugar Beet & SRC & Rapeseed & Potato \\
\hline \multirow{3}{*}{ Theoretical potential } & Wet mass range ${ }^{6}$ & $\mathrm{t} / \mathrm{ha}$ a & $40-85$ & $4-18$ & $8.5-13.5$ & $33-50$ \\
\hline & Water content ${ }^{6}$ & $\%$ & 76 & 29 & 12 & 76 \\
\hline & Heating value ${ }^{4,5,8}$ & $\mathrm{MJ} / \mathrm{kg}$ & 17.4 & 18.5 & 18.0 & 18.0 \\
\hline \multirow[b]{2}{*}{ Biogas } & $\begin{array}{c}\text { oTS Organic dry mass of dry } \\
\text { mass } 7\end{array}$ & $\%$ & 92 & 91 & 85 & 90 \\
\hline & Biogas yield $^{7}$ & 1_N/kg oTS & 700 & 516 & 630 & 640 \\
\hline \multirow{2}{*}{$\begin{array}{c}\text { Bioethanol } \\
\text { Biodiesel }\end{array}$} & Conversion efficiency ${ }^{3}$ & GJ/GJ_Primary & 0.8 & 0.4 & - & 0.6 \\
\hline & Conversion efficiency ${ }^{3}$ & GJ/GJ_Primary & - & - & 0.3 & - \\
\hline \multirow[b]{2}{*}{ Residue } & Yield range ${ }^{1,2}$ & $\mathrm{t} F \mathrm{FM} /($ ha a $)$ & $10.0-32.0$ & $2.5-4$ & $4.2-10$ & $10-32$ \\
\hline & Residue yield factor & $\begin{array}{l}\text { t_residue FM/ } \\
\text { t_biomass FM }\end{array}$ & 0.3 & 0.3 & 0.6 & 0.5 \\
\hline
\end{tabular}

1,2,3,4 Flaig, Holger, and Hans Mohr, eds. Energie aus Biomasse, pp. 280-281,275,337,609; 5,6,7 Faustzahlen für die Landwirtschaft, pp. 917,299-300,913,938-940; ${ }^{8}$ Bayerisches Staatsministerium für Ernährung, Landwirtschaft und Forsten (StMELF), Biogasausbeuten-Datenbank; ${ }^{9}$ Heat value of sugar beet, silphy, ochard meadow are not give, average value $17.8 \mathrm{MJ} / \mathrm{kg}$ taken.

\section{Appendix C}

Table A3. Key parameters of crops for biomass yield simulation.

\begin{tabular}{|c|c|c|c|c|c|c|}
\hline Parameter & Winter Cereal & Spring Cereal & Maize & Sugar Beet & Potato & SRC \\
\hline Base temperature ${ }^{\circ} \mathrm{C}$ & 5 & 0 & 8 & 5 & 2 & 0 \\
\hline Upper temperature ${ }^{\circ} \mathrm{C}$ & 35 & 26 & 30 & 30 & 26 & 25 \\
\hline Plant density (Plants per ha) & $2,000,000$ & $4,500,000$ & 75,000 & 100,000 & 40,000 & 266,667 \\
\hline Plant to emergence (GDD) & 88 & 150 & 80 & 23 & 200 & 0 \\
\hline $\begin{array}{l}\text { Planting to maximum rooting depth } \\
\text { (GDD) }\end{array}$ & 720 & 864 & 1409 & 408 & 1079 & 3080 \\
\hline Planting to start senescence (GDD) & 819 & 1700 & 1400 & 1704 & 984 & 2410 \\
\hline Planting to maturity (GDD) & 2162 & 2400 & 1700 & 2203 & 1276 & 3080 \\
\hline Planting to flowering (GDD) & 754 & 1250 & 880 & 865 & 550 & 0 \\
\hline Maximum rooting depth $(\mathrm{m})$ & 1.2 & 1.5 & 2.3 & 1 & 1.5 & 0.8 \\
\hline $\begin{array}{l}\text { Maximum canopy cover in fraction } \\
\text { soil cover }\end{array}$ & 0.91 & 0.96 & 0.96 & 0.98 & 0.92 & 0.96 \\
\hline $\begin{array}{l}\text { Water productivity normalized for } \\
\qquad \mathrm{ET}_{0} \text { and } \mathrm{CO}_{2}\left(\mathrm{~g} / \mathrm{m}^{2}\right)\end{array}$ & 15 & 15 & 33.7 & 17 & 18 & 10.4 \\
\hline $\begin{array}{l}\text { Canopy growth coefficient (CGC) } \\
\text { (fraction soil cover per day) (GDD) }\end{array}$ & 0.02833 & 0.005001 & 0.012494 & 0.010541 & 0.01615 & 0.003543 \\
\hline $\begin{array}{c}\text { Canopy decline coefficient (CDC): } \\
\text { decrease in canopy cover (in fraction } \\
\text { per day) (GDD) }\end{array}$ & 0.0668 & 0.004 & 0.01 & 0.003857 & 0.002 & 0.00383 \\
\hline $\begin{array}{l}\text { Soil water depletion factor for canopy } \\
\text { expansion, upper limit }\end{array}$ & 0.25 & 0.2 & 0.14 & 0.2 & 0.2 & 0.25 \\
\hline $\begin{array}{l}\text { Soil water depletion factor for canopy } \\
\text { expansion, lower limit }\end{array}$ & 0.55 & 0.65 & 0.72 & 0.6 & 0.6 & 0.55 \\
\hline $\begin{array}{l}\text { Shape factor for water stress } \\
\text { coefficient for canopy expansion }\end{array}$ & 4 & 5 & 2.9 & 3 & 3 & 0 \\
\hline $\begin{array}{l}\text { Soil water depletion factor for } \\
\text { pollination (p-pol), upper threshold }\end{array}$ & 0.9 & 0.85 & 0.8 & 0.8 & 0.8 & 0.9 \\
\hline $\begin{array}{l}\text { Shape factor for water stress } \\
\text { coefficient for stomatal closure }\end{array}$ & 3 & 2.5 & 6 & 3 & 3 & 0 \\
\hline $\begin{array}{l}\text { Shape factor for water stress } \\
\text { coefficient for canopy senescence }\end{array}$ & 3 & 2.5 & 2.7 & 3 & 3 & 0 \\
\hline
\end{tabular}


Table A4. Continued table: Key parameters of crops for biomass yield simulation.

\begin{tabular}{|c|c|c|}
\hline Parameter & Winter Cereal & Spring Cereal \\
\hline Base temperature ${ }^{\circ} \mathrm{C}$ & 5 & 0 \\
\hline Upper temperature ${ }^{\circ} \mathrm{C}$ & 30 & 30 \\
\hline Plant density (Plants per ha) & 60,000 & 440,000 \\
\hline Plant to emergence (Calendar Days) & 11 & 7 \\
\hline Planting to maximum rooting depth (Calendar Days) & 124 & 70 \\
\hline Planting to start senescence (Calendar Days) & 209 & 120 \\
\hline Planting to maturity (Calendar Days) & 244 & 206 \\
\hline Planting to flowering (Calendar Days) & 0 & 87 \\
\hline Maximum rooting depth $(\mathrm{m})$ & 0.7 & 0.3 \\
\hline Maximum canopy cover in fraction soil cover & 0.75 & 0.8 \\
\hline Water productivity normalized for $\mathrm{ET}_{0}$ and $\mathrm{CO}_{2}\left(\mathrm{~g} / \mathrm{m}^{2}\right)$ & 14 & 18.6 \\
\hline Canopy growth coefficient (CGC) (fraction soil cover per day) (Calendar Days) & 0.04626 & 0.09713 \\
\hline $\begin{array}{l}\text { Canopy decline coefficient (CDC): decrease in canopy cover (in fraction per day) } \\
\text { (Calendar Days) }\end{array}$ & 0.17 & 0.052 \\
\hline
\end{tabular}

Table A4. Cont.

\begin{tabular}{ccc}
\hline Parameter & Winter Cereal & Spring Cereal \\
\hline Soil water depletion factor for canopy expansion, upper limit & 0 & 0.2 \\
\hline Soil water depletion factor for canopy expansion, lower limit & 0.35 & 0.55 \\
\hline Shape factor for water stress coefficient for canopy expansion & 2.5 & 3.5 \\
\hline Soil water depletion factor for pollination (p-pol), upper threshold & 0.9 & 0.9 \\
\hline Shape factor for water stress coefficient for stomatal closure & 2 & 5 \\
\hline Shape factor for water stress coefficient for canopy senescence & 2 & 3 \\
\hline
\end{tabular}

\section{Appendix D}

Table A5. Default parameter values used in modelling local bioenergy potentials.

\begin{tabular}{|c|c|c|}
\hline Parameter & Default Value & Explanation \\
\hline Conifer trees harvest rate & $4.5 \%[23]$ & $\begin{array}{l}\text { The percentage in volume of conifer trees harvested annually out of all } \\
\text { conifer trees }\end{array}$ \\
\hline Deciduous trees harvest rate & $3.0 \%[23]$ & $\begin{array}{l}\text { The percentage in volume of deciduous trees harvested annually out of all } \\
\text { deciduous trees }\end{array}$ \\
\hline Forest energy usage rate & $25.6 \%[25]$ & $\begin{array}{l}\text { The percentage in volume of solid forest wood with diameters }>7 \mathrm{~cm} \text { that is } \\
\text { used for energy purposes }\end{array}$ \\
\hline Energy crop rate & $14.0 \%[29]$ & $\begin{array}{l}\text { The percentage of farmland area used for energy crop cultivation (e.g., rapeseed, } \\
\text { maize). Energy crops are used exclusively for energetic purposes. Since no data } \\
\text { source gives information on the end product of a crop (energy or food) per field, } \\
\text { we assume, in line with statistical data, that } 14 \% \text { of each field's area is used for } \\
\text { energetic purposes. }\end{array}$ \\
\hline Residue energy usage rate & $62.0 \%[30]$ & The percentage of residue by-products which are used for energetic purposes. \\
\hline $\begin{array}{l}\text { Rate of maize residue for } \\
\text { Biogas production }\end{array}$ & $39.4 \%[29,31]$ & $\begin{array}{l}\text { The percentage of maize residue (silage) for biogas production. The rest of maize } \\
\text { residue of maize is used as solid fuel. }\end{array}$ \\
\hline
\end{tabular}


Table A6. Distribution of energy crop yields among different forms of possible secondary energy carriers. Source: FNR [23].

\begin{tabular}{ccccc}
\hline Crop & Biogas & Bioethanol & Vegetable Oil & Solid Fuel \\
\hline Cereal & $57 \%$ & $43 \%$ & - & - \\
Maize & - & $100 \%$ & - & - \\
Short-rotation coppice (SRC) & - & - & - & $100 \%$ \\
Sugar beet & $42 \%$ & $58 \%$ & - & - \\
Rapeseed & - & - & $100 \%$ & - \\
Grass & $98 \%$ & - & $0 \%$ & $2 \%$ \\
\hline
\end{tabular}

\section{Appendix E}

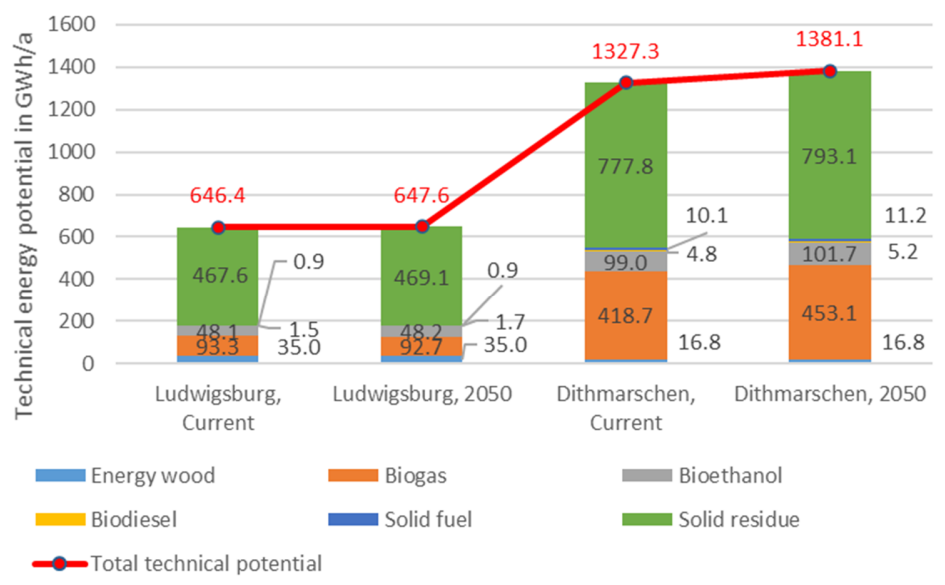

Figure A1. Technical bioenergy potential in current climate and in year 2050 in Ludwigsburg and Dithmarschen.

\section{References}

1. Scarlat, N.; Dallemand, J.F.; Taylor, N.; Banja, M.; Sanchez Lopez, J.; Avraamides, M. Brief on Biomass for Energy in the European Union; Publications Office of the European Union: Luxembourg, 2019; ISBN 927977235X.

2. German National Academy of Sciences Leopoldina; acatech-National Academy of Science and Engineering; Union of the German Academies of Sciences and Humanities. Biomass: Striking a Balance between Energy and Climate Policies. Strategies for Sustainable Bioenergy Use; acatech-National Academy of Science and Engineering: Munich, Germany; German National Academy of Sciences Leopoldina: Schweinfurt, Germany; Union of the German Academies of Sciences and Humanities: Munich, Germany, 2019; ISBN 978-3-8047-3929-1.

3. Berndes, G.; Hoogwijk, M.; van den Broek, R. The contribution of biomass in the future global energy supply: A review of 17 studies. Biomass Bioenergy 2003, 25, 1-28. [CrossRef]

4. Mittelstädt, A.; Köhler, S.; Sihombing, R.; Duminil, E.; Coors, V.; Eicker, U.; Schröter, B. (Eds.) A Multi-Scale, Web-Based Interface for Strategic Planning of Low-Carbon City Quarters, Proceedings of the Second International Conference on Urban Informatics, Hong Kong, China, 24-26 June 2019; The Hong Kong Polytechnic University: Hong Kong, China, 2019.

5. Braun, R.; Weiler, V.; Zirak, M.; Dobisch, L.; Coors, V.; Eicker, U. Using 3D CityGML Models for Building Simulation Applications at District Level. In Proceedings of the 2018 IEEE International Conference on Engineering, Technology and Innovation (ICE/ITMC), Stuttgart, Germany, 17-20 June 2018; pp. 1-8.

6. Bouchard, S.; Landry, M.; Gagnon, Y. Methodology for the large scale assessment of the technical power potential of forest biomass: Application to the province of New Brunswick, Canada. Biomass Bioenergy 2013, 54, 1-17. [CrossRef]

7. Ericsson, K.; Nilsson, L.J. Assessment of the potential biomass supply in Europe using a resource-focused approach. Biomass Bioenergy 2006, 30, 1-15. [CrossRef]

8. Lauka, D.; Barisa, A.; Blumberga, D. Assessment of the availability and utilization potential of low-quality biomass in Latvia. Energy Procedia 2018, 147, 518-524. [CrossRef] 
9. Haase, M.; Rösch, C.; Ketzer, D. GIS-based assessment of sustainable crop residue potentials in European regions. Biomass Bioenergy 2016, 86, 156-171. [CrossRef]

10. Lozano-García, D.F.; Santibañez-Aguilar, J.E.; Lozano, F.J.; Flores-Tlacuahuac, A. GIS-based modeling of residual biomass availability for energy and production in Mexico. Renew. Sustain. Energy Rev. 2020, 120, 109610. [CrossRef]

11. Quinta-Nova, L.; Fernandez, P.; Pedro, N. GIS-Based Suitability Model for Assessment of Forest Biomass Energy Potential in a Region of Portugal. IOP Conf. Ser. Earth Environ. Sci. 2017, 95, 42059. [CrossRef]

12. Voivontas, D.; Assimacopoulos, D.; Koukios, E.G. Assessment of biomass potential for power production: A GIS based method. Biomass Bioenergy 2001, 20, 101-112. [CrossRef]

13. Padsala, R.; Coors, V. Conceptualizing, Managing and Developing: A Web Based 3D City Information Model for Urban Energy Demand Simulation. 2307-8251. 2015. [CrossRef]

14. Rodríguez, L.R.; Duminil, E.; Ramos, J.S.; Eicker, U. Assessment of the photovoltaic potential at urban level based on 3D city models: A case study and new methodological approach. Solar Energy 2017, 146, $264-275$. [CrossRef]

15. Arbeitsgemeinschaft der Vermessungsverwaltungen der Länder der Bundesrepublik Deutschland. Digitales Basis-Landschaftsmodell (Basis-DLM). Available online: http://www.adv-online.de/AdV-Produkte/ Geotopographie/Digitale-Landschaftsmodelle/Basis-DLM/ (accessed on 10 November 2020).

16. Griffiths, P.; Nendel, C.; Hostert, P. Intra-annual reflectance composites from Sentinel-2 and Landsat for national-scale crop and land cover mapping. Remote Sens. Environ. 2019, 220, 135-151. [CrossRef]

17. Wyland, L.J.; Jackson, L.E.; Chaney, W.E.; Klonsky, K.; Koike, S.T.; Kimple, B. Winter cover crops in a vegetable cropping system: Impacts on nitrate leaching, soil water, crop yield, pests and management costs. Agric. Ecosyst. Environ. 1996, 59, 1-17. [CrossRef]

18. Searle, S.Y.; Malins, C.J. Will energy crop yields meet expectations? Biomass Bioenergy 2014, 65, 3-12. [CrossRef]

19. Bundesanstalt für Geowissenschaften und Rohstoffe. Karte der Bodenarten in Oberböden 1:1.000.000 (BOART1000OB). Available online: https:/www.bgr.bund.de/DE/Themen/Boden/Informationsgrundlagen/ Bodenkundliche_Karten_Datenbanken/Themenkarten/BOART1000OB/boart1000ob_node.html (accessed on 24 September 2020).

20. Kolbe, T.H.; Gröger, G.; Plümer, L. CityGML: Interoperable Access to 3D City Models. In Geo-Information for Disaster Management; Fendel, E.M., van Oosterom, P., Zlatanova, S., Eds.; Springer: Berlin/Heidelberg, Germany, 2005; pp. 883-899. ISBN 978-3-540-27468-1.

21. Nouvel, R.; Brassel, K.-H.; Bruse, M.; Duminil, E.; Coors, V.; Eicker, U. SimStadt, a New Workflow-Driven Urban Energy Simulation Platform for CityGML City Models. In Proceedings of the International Conference CISBAT 2015 Future Buildings and Districts Sustainability from Nano to Urban Scale. No. CONF. LESO-PB, EPFL, Lausanne, Switzerland, 9-11 September 2015.

22. Statistisches Landesamt Baden-Württemberg. Flächenerhebung nach Art der tatsächlichen Nutzung 2015. Available online: https:/www.statistischebibliothek.de/mir/servlets/MCRFileNodeServlet/BWHeft_derivate_ 00008321/3336_15001.pdf (accessed on 2 December 2020).

23. Martin, K.; Hans, H.; Hermann, H. Energie aus Biomasse: Grundlagen, Techniken und Verfahren; Springer: Berlin/Heidelberg, Germany, 2001.

24. Food and Agriculture Organization of the United Nations. Introductin AquaCrop. Available online: http://www.fao.org/aquacrop/en (accessed on 26 October 2020).

25. Mantau, U.; Döring, P.; Weimar, H.; Glasenapp, S.; Jochem, D.; Zimmermann, K. Rohstoffmonitoring Holz: Erwartungen und Möglichkeite; Fachagentur Nachwachsende Rohstoffe e. V. (FNR): Gülzow-Prüzen, Germany, 2018.

26. Kath, J.; Reardon-Smith, K.; Le Brocque, A.F.; Dyer, F.J.; Dafny, E.; Fritz, L.; Batterham, M. Groundwater decline and tree change in floodplain landscapes: Identifying non-linear threshold responses in canopy condition. Glob. Ecol. Conserv. 2014, 2, 148-160. [CrossRef]

27. Weiler, V.; Stave, J.; Eicker, U. Renewable Energy Generation Scenarios Using 3D Urban Modeling Tools-Methodology for Heat Pump and Co-Generation Systems with Case Study Application. Energies 2019, 12, 403. [CrossRef]

28. Allen, R.G. Crop Evapotranspiration-Guidelines for Computing Crop Water Requirements; FAO: Rome, Italy, 1998; ISBN 9251042195. 
29. Rohstoffe, F.N. Anbau und Verwendung nachwachsender Rohstoffe in Deutschland 2019. Available online: https://www.weltagrarbericht.de/fileadmin/files/weltagrarbericht/Weltagrarbericht/ 16AgrarspritBioenergie/FNR2019.pdf (accessed on 26 October 2020).

30. Nitsch, J.; Pregger, T.; Naegler, T.; Heide, D.; Luca de Tena, D.; Trieb, F.; Scholz, Y.; Nienhaus, K.; Gerhardt, N.; Sterner, M.; et al. Langfristszenarien und Strategien für den Ausbau der Erneuerbaren Energien in Deutschland bei Berücksichtigung der Entwicklung in Europa und Global; Federal Ministry for the Environment, Nature Conservation and Nuclear Safety: Berlin, Germany, 2012.

31. Statistisches Bundesamt. Anbauflächen, Hektarerträge und Erntemengen ausgewählter Anbaukulturen im Zeitvergleich. Available online: https://www.destatis.de/DE/Themen/Branchen-Unternehmen/ Landwirtschaft-Forstwirtschaft-Fischerei/Feldfruechte-Gruenland/Tabellen/liste-feldfruechte-zeitreihe. html (accessed on 1 October 2020).

32. Döhler, H. (Ed.) Faustzahlen für die Landwirtschaft; völlig neu bearb; Kuratorium für Technik und Bauwesen in der Landwirtschaft e.V.(KTBL): Darmstadt, Germany, 2005; ISBN 3784321941.

33. Statistisches Landesamt Baden-Württemberg. Flächen für Landwirtschaft in den Kreisen Baden-Württembergs. Statistisches Monatsheft Baden-Württemberg 9/2018 2018, 55-59.

34. Ulich, E.; Geruhn, A.; Demmer, H.; Frank, K. Regionalprofil 2006 des Kreises Dithmarschen. Einschließlich Stäken- und Schwächen-Analyse. Available online: https://www.dithmarschen.de/media/ custom/647_2783_1.PDF (accessed on 26 May 2020).

35. Thüringer Landesamt für Statistik. Available online: https://statistik.thueringen.de/startseite.asp (accessed on 20 August 2020).

36. Global Yield Gap Atlas. Available online: http://www.yieldgap.org/home (accessed on 5 October 2020).

37. Actual Yield Determination-Global Yield Gap Atlas. Available online: http://www.yieldgap.org/web/guest/ methods-actual-yield (accessed on 5 October 2020).

38. Xiying, Z.; Suying, C.; Hongyong, S.; Dong, P.; Yanmei, W. Dry matter, harvest index, grain yield and water use efficiency as affected by water supply in winter wheat. Irrig. Sci. 2008, 27, 1-10. [CrossRef]

39. Echarte, L.; Andrade, F.H. Harvest index stability of Argentinean maize hybrids released between 1965 and 1993. Field Crops Res. 2003, 82,1-12. [CrossRef]

40. Öko-Institut. Modell Deutschland. Klimaschutz bis 2050: Vom Ziel her Denken. Available online: https://www. wwf.de/fileadmin/fm-wwf/Publikationen-PDF/WWF_Modell_Deutschland_Endbericht.pdf (accessed on 2 December 2020).

41. Nitsch, J.; Krewitt, W.; Nast, M.; Viebahn, P.; Gärtner, S.; Pehnt, M.; Reinhardt, G.; Schmidt, R.; Uihlein, A.; Barthel, C.; et al. Ökologisch Optimierter Ausbau der Nutzung Erneurbarer Energie in Deutschland. 2004. Available online: https://www.ise.fraunhofer.de/content/dam/ise/en/documents/publications/studies/recentfacts-about-photovoltaics-in-germany.pdf (accessed on 2 December 2020).

42. Meteonorm. Available online: https://meteonorm.com/en/ (accessed on 12 August 2020).

43. Landratsamt Ludwigsburg. Klimaschutzkonzept Ludwigsburg Kurzbericht. 2015. Available online: https://www.landkreis-ludwigsburg.de/fileadmin/user_upload/seiteninhalte/natur-umwelt/umwelt/ klimaschutz/20151007_endbericht_band1_klimaschutzkonzept.pdf (accessed on 5 October 2020).

44. Statistisches Landesamt Baden-Württemberg. Struktur und Entwicklung des Energieverbrauchs nach Verbrauchsart und Verbrauchergruppen. Available online: https:/www.statistik-bw.de/Energie/ Energiebilanz/LRt1002.jsp (accessed on 24 June 2020).

45. Kreis Dithmarschen. Integriertes Klimaschutzkonzept für den Kreis Dithmarschen. Available online: https://www.dithmarschen.de/media/custom/647_8081_1.PDF (accessed on 20 October 2020).

46. Statistisches Amt für Hamburg und Schleswig-Holstein. Energie- und CO2-Bilanzen für Schleswig-Holstein-Statistikamt Nord. Available online: https://www.statistik-nord.de/zahlen-fakten/ umwelt-energie/energie/dokumentenansicht/product/6207/energie-und-co2-bilanzen-fuer-schleswigholstein-360?cHash=653b32db13abf009ce4a187a9911a9fa (accessed on 20 October 2020).

47. Directive (EU) 2018/2001 on the Promotion of the Use of Energy from Renewable Sources. European PARLIAMENT and of the Council. 2018. Available online: https://eur-lex.europa.eu/legalcontent/EN/LSU/?uri=uriserv:OJ.L_.2018.328.01.0082.01.ENG (accessed on 2 December 2020).

48. Meisel, K.; Millinger, M.; Naumann, K.; Müller-Langer, F.; Majer, S.; Thrän, D. Future Renewable Fuel Mixes in Transport in Germany under RED II and Climate Protection Targets. Energies 2020, 13, 1712. [CrossRef] 
49. Biofuel Chain Development in Germany: Organisation, Opportunities, and Challenges. Available online: https://www.sciencedirect.com/science/article/pii/S0301421507003436 (accessed on 8 October 2020).

50. Bao, K.; Padsala, R.; Coors, V.; Thrän, D.; Schröter, B. GIS-Based Assessment of Regional Biomass Potentials at the Example of Two Counties in Germany. Eur. Biomass Conf. Exhib. Proc. 2020, 77-85. [CrossRef]

51. Verón, S.R.; De Abelleyra, D.; Lobell, D.B. Impacts of precipitation and temperature on crop yields in the Pampas. Clim. Chang. 2015, 130, 235-245. [CrossRef]

52. Millinger, M.; Meisel, K.; Thrän, D. Greenhouse gas abatement optimal deployment of biofuels from crops in Germany. Transp. Res. Part D: Transp. Environ. 2019, 69, 265-275. [CrossRef]

53. Bao, K.; Padsala, R.; Thrän, D.; Schröter, B. Urban Water Demand Simulation in Residential and Non-Residential Buildings Based on a CityGML Data Model. ISPRS Int. J. Geo-Inf. 2020, 9, 642. [CrossRef]

54. Robledo, C.B.; Oldenbroek, V.; Abbruzzese, F.; van Wijk, A.J.M. Integrating a hydrogen fuel cell electric vehicle with vehicle-to-grid technology, photovoltaic power and a residential building. Appl. Energy 2018, 215, 615-629. [CrossRef]

55. Pradhan, P.; Kriewald, S.; Costa, L.; Rybski, D.; Benton, T.G.; Fischer, G.; Kropp, J.P. Urban Food Systems: How Regionalization Can Contribute to Climate Change Mitigation. Environ. Sci. Technol. 2020, 54, 10551-10560. [CrossRef]

Publisher's Note: MDPI stays neutral with regard to jurisdictional claims in published maps and institutional affiliations.

(C) 2020 by the authors. Licensee MDPI, Basel, Switzerland. This article is an open access article distributed under the terms and conditions of the Creative Commons Attribution (CC BY) license (http://creativecommons.org/licenses/by/4.0/). 